\title{
The role of chlorine in global tropospheric chemistry
}

\author{
Xuan Wang $^{1}$, Daniel J. Jacob ${ }^{1,2}$, Sebastian D. Eastham ${ }^{3}$, Melissa P. Sulprizio ${ }^{1}$, Lei Zhu ${ }^{1}$, Qianjie Chen ${ }^{4}$, \\ Becky Alexander $^{5}$, Tomás Sherwen ${ }^{6,7}$, Mathew J. Evans ${ }^{6,7}$, Ben H. Lee ${ }^{5}$, Jessica D. Haskins ${ }^{5}$, \\ Felipe D. Lopez-Hilfiker ${ }^{8}$, Joel A. Thornton ${ }^{5}$, Gregory L. Huey ${ }^{9}$, and Hong Liao ${ }^{10}$ \\ ${ }^{1}$ School of Engineering and Applied Sciences, Harvard University, Cambridge, Massachusetts, USA \\ ${ }^{2}$ Department of Earth and Planetary Sciences, Harvard University, Cambridge, Massachusetts, USA \\ ${ }^{3}$ Laboratory for Aviation and the Environment, Massachusetts Institute of Technology, Cambridge, Massachusetts, USA \\ ${ }^{4}$ Department of Chemistry, University of Michigan, Ann Arbor, Michigan, USA \\ ${ }^{5}$ Department of Atmospheric Sciences, University of Washington, Seattle, USA \\ ${ }^{6}$ Wolfson Atmospheric Chemistry Laboratories, Department of Chemistry, University of York, York, UK \\ ${ }^{7}$ National Centre for Atmospheric Science, University of York, York, UK \\ ${ }^{8}$ Laboratory of Atmospheric Chemistry, Paul Scherrer Institute, Villigen, Switzerland \\ ${ }^{9}$ School of Earth and Atmospheric Science, Georgia Institute of Technology, Atlanta, GA, USA \\ ${ }^{10}$ School of Environmental Science and Engineering, Nanjing University \\ of Information Science and Technology, Nanjing, China
}

Correspondence: Xuan Wang (wangx@ seas.harvard.edu)

Received: 11 October 2018 - Discussion started: 19 October 2018

Revised: 3 March 2019 - Accepted: 6 March 2019 - Published: 29 March 2019

\begin{abstract}
We present a comprehensive simulation of tropospheric chlorine within the GEOS-Chem global 3-D model of oxidant-aerosol-halogen atmospheric chemistry. The simulation includes explicit accounting of chloride mobilization from sea salt aerosol by acid displacement of $\mathrm{HCl}$ and by other heterogeneous processes. Additional small sources of tropospheric chlorine (combustion, organochlorines, transport from stratosphere) are also included. Reactive gasphase chlorine $\mathrm{Cl}^{*}$, including $\mathrm{Cl}, \mathrm{ClO}, \mathrm{Cl}_{2}, \mathrm{BrCl}, \mathrm{ICl}, \mathrm{HOCl}$, $\mathrm{ClNO}_{3}, \mathrm{ClNO}_{2}$, and minor species, is produced by the $\mathrm{HCl}+$ $\mathrm{OH}$ reaction and by heterogeneous conversion of sea salt aerosol chloride to $\mathrm{BrCl}, \mathrm{ClNO}_{2}, \mathrm{Cl}_{2}$, and ICl. The model successfully simulates the observed mixing ratios of $\mathrm{HCl}$ in marine air (highest at northern midlatitudes) and the associated $\mathrm{HNO}_{3}$ decrease from acid displacement. It captures the high $\mathrm{ClNO}_{2}$ mixing ratios observed in continental surface air at night and attributes the chlorine to $\mathrm{HCl}$ volatilized from sea salt aerosol and transported inland following uptake by fine aerosol. The model successfully simulates the vertical profiles of $\mathrm{HCl}$ measured from aircraft, where enhancements in the continental boundary layer can again be largely explained by transport inland of the marine source. It does not reproduce the boundary layer $\mathrm{Cl}_{2}$ mixing ratios measured in
\end{abstract}

the WINTER aircraft campaign (1-5 ppt in the daytime, low at night); the model is too high at night, which could be due to uncertainty in the rate of the $\mathrm{ClNO}_{2}+\mathrm{Cl}^{-}$reaction, but we have no explanation for the high observed $\mathrm{Cl}_{2}$ in daytime. The global mean tropospheric concentration of $\mathrm{Cl}$ atoms in the model is $620 \mathrm{~cm}^{-3}$ and contributes $1.0 \%$ of the global oxidation of methane, $20 \%$ of ethane, $14 \%$ of propane, and $4 \%$ of methanol. Chlorine chemistry increases global mean tropospheric $\mathrm{BrO}$ by $85 \%$, mainly through the $\mathrm{HOBr}+\mathrm{Cl}^{-}$ reaction, and decreases global burdens of tropospheric ozone by $7 \%$ and $\mathrm{OH}$ by $3 \%$ through the associated bromine radical chemistry. $\mathrm{ClNO}_{2}$ chemistry drives increases in ozone of up to $8 \mathrm{ppb}$ over polluted continents in winter.

\section{Introduction}

Mobilization of chloride $\left(\mathrm{Cl}^{-}\right)$from sea salt aerosol (SSA) is a large source of chlorine gases to the troposphere (Graedel and Keene, 1995; Finlayson-Pitts, 2003). These gases may generate chlorine radicals with a broad range of implications for tropospheric chemistry including the budgets of ozone, $\mathrm{OH}$ (the main tropospheric oxidant), volatile organic com- 
pounds (VOCs), nitrogen oxides, other halogens, and mercury (Saiz-Lopez and von Glasow, 2012; Simpson et al., 2015). Only a few global models have attempted to examine the implications of tropospheric chlorine chemistry on a global scale (Singh and Kasting, 1988; Long et al., 2014; Hossaini et al., 2016). Here we present a more comprehensive analysis of this chemistry within the framework of the GEOS-Chem chemical transport model (CTM).

Saiz-Lopez and von Glasow (2012) and Simpson et al. (2015) present recent reviews of tropospheric halogen chemistry including chlorine. Sea salt aerosols represent a large chloride flux to the atmosphere but most of that chloride is removed rapidly by deposition. Only a small fraction is mobilized to the gas phase as $\mathrm{HCl}$ or other species. Additional minor sources of tropospheric chlorine include open fires, coal combustion, waste incineration, industry, road salt application, fugitive dust, and ocean emission of organochlorine compounds (Lobert et al., 1999; McCulloch et al., 1999; Sarwar et al., 2012; WMO, 2014; Kolesar et al., 2018). It is useful to define $\mathrm{Cl}_{y}$ as total gas-phase inorganic chlorine, excluding particle-phase $\mathrm{Cl}^{-}$. Most of this $\mathrm{Cl}_{y}$ is present as $\mathrm{HCl}$, which is removed rapidly by deposition but also serves as a source of chlorine radicals. Rapid cycling takes place between the chlorine radicals and other chlorine gases, eventually returning to $\mathrm{HCl}$. Thus it is useful to define reactive chlorine $\mathrm{Cl}^{*}$ as the ensemble of $\mathrm{Cl}_{y}$ gases other than $\mathrm{HCl}$.

Cycling of chlorine affects tropospheric chemistry in a number of ways (Finlayson-Pitts, 2003; Saiz-Lopez and von Glasow, 2012). Acid displacement of $\mathrm{Cl}^{-}$by nitric acid $\left(\mathrm{HNO}_{3}\right)$ is a source of $\mathrm{NO}_{3}^{-}$aerosol (Massucci et al., 1999). $\mathrm{Cl}$ atoms provide a sink for methane, other VOCs (Atkinson, 1997), dimethyl sulfide (DMS) (Hoffmann et al., 2016; Chen et al., 2017), and mercury (Horowitz et al., 2017). Cycling between $\mathrm{Cl}$ radicals and their reservoirs drives catalytic ozone loss and converts nitrogen oxide radicals $\left(\mathrm{NO}_{x} \equiv\right.$ $\mathrm{NO}+\mathrm{NO}_{2}$ ) to $\mathrm{HNO}_{3}$, decreasing both ozone and $\mathrm{OH}$. Conversely, aqueous-phase reaction of $\mathrm{Cl}^{-}$with $\mathrm{N}_{2} \mathrm{O}_{5}$ in polluted environments produces $\mathrm{ClNO}_{2}$ radicals that photolyze in the daytime to return $\mathrm{Cl}$ atoms and $\mathrm{NO}_{2}$, stimulating ozone production (Behnke et al., 1997; Osthoff et al., 2008). Chlorine also interacts with other halogens (bromine, iodine), initiating further radical chemistry that affects ozone, $\mathrm{OH}$, and mercury.

A number of global modeling studies have investigated tropospheric halogen chemistry but most have focused on bromine and iodine, which are more active than chlorine because of the lower chemical stability of $\mathrm{HBr}$ and $\mathrm{HI}$ (Yang et al., 2005; Saiz-Lopez et al., 2014). Interest in global modeling of tropospheric chlorine has focused principally on quantifying the $\mathrm{Cl}$ atom concentration as a sink for methane (Keene et al., 1990; Singh et al., 1996). Previous global 3$\mathrm{D}$ models found mean tropospheric $\mathrm{Cl}$ atom concentrations of the order of $10^{3} \mathrm{~cm}^{-3}$, with values up to $10^{4} \mathrm{~cm}^{-3}$ in the marine boundary layer (MBL), and contributing 2\%-3\% of atmospheric methane oxidation (Long et al., 2014; Hossaini et al., 2016; Sherwen et al., 2016b; Schmidt et al., 2016). A regional modeling study by Sarwar et al. (2014) included $\mathrm{ClNO}_{2}$ chemistry in a standard ozone mechanism and found increases in surface ozone mixing ratios over the US of up to $7 \mathrm{ppb}\left(\mathrm{ppb} \equiv \mathrm{nmol} \mathrm{mol}^{-1}\right)$.

Here we present a more comprehensive analysis of global tropospheric chlorine chemistry and its implications, building on previous model development of oxidant-aerosolhalogen chemistry in GEOS-Chem. A first capability for modeling tropospheric bromine in GEOS-Chem was introduced by Parrella et al. (2012). Eastham et al. (2014) extended it to describe stratospheric halogen chemistry including chlorine and bromine cycles. Schmidt et al. (2016) updated the tropospheric bromine simulation to include a broader suite of heterogeneous processes and extended the Eastham et al. (2014) stratospheric chlorine scheme to the troposphere. Sherwen et al. (2016a, b) added iodine chemistry and made further updates to achieve a consistent representation of tropospheric chlorine-bromine-iodine chemistry in GEOS-Chem. Chen et al. (2017) added the aqueousphase oxidation of $\mathrm{SO}_{2}$ by $\mathrm{HOBr}$ and found a large effect on the MBL bromine budget. Our work advances the treatment of tropospheric chlorine in GEOS-Chem to include, in particular, a consistent treatment of SSA chloride and chlorine gases, SSA acid displacement thermodynamics, improved representation of heterogeneous chemistry, and better accounting of chlorine sources. We evaluate the model with a range of global observations for chlorine and related species. From there we quantify the global tropospheric chlorine budgets, describe the principal chemical pathways, and explore the impacts on tropospheric chemistry.

\section{Model description}

\subsection{GEOS-Chem model with $\mathrm{Cl}+\mathrm{Br}+\mathrm{I}$ halogen chemistry}

We build our new tropospheric chlorine simulation capability onto the standard version 11-02d of GEOS-Chem (http://www.geos-chem.org, last access: 1 March 2019). The standard version includes a detailed tropospheric oxidantaerosol-halogen mechanism as described by Sherwen et al. (2016b) and Chen et al. (2017). It includes 12 gas-phase $\mathrm{Cl}_{y}$ species: $\mathrm{Cl}, \mathrm{Cl}_{2}, \mathrm{Cl}_{2} \mathrm{O}_{2}, \mathrm{ClNO}_{2}, \mathrm{ClNO}_{3}, \mathrm{ClO}, \mathrm{ClOO}$, $\mathrm{OClO}, \mathrm{BrCl}, \mathrm{ICl}, \mathrm{HOCl}$, and $\mathrm{HCl}$. It allows for heterogeneous chemistry initiated by $\mathrm{SSA} \mathrm{Cl}^{-}$but does not actually track the SSA $\mathrm{Cl}^{-}$concentration and its exchange with gas-phase $\mathrm{Cl}_{y}$. Here we add two new transported reactive species to GEOS-Chem to describe $\mathrm{Cl}^{-}$aerosol, one for the fine mode $(<1 \mu \mathrm{m}$ diameter $)$ and one for the coarse mode ( $>1 \mu \mathrm{m}$ diameter). The standard GEOS-Chem wet deposition schemes for water-soluble aerosols (Liu et al., 2001) and gases (Amos et al., 2012) are applied to $\mathrm{Cl}^{-}$aerosol and $\mathrm{Cl}_{y}$ gases, respectively, the latter with Henry's law con- 
stants from Sander (2015). Dry deposition of $\mathrm{Cl}^{-}$aerosol follows that of SSA (Jaeglé et al., 2011), and dry deposition of $\mathrm{Cl}_{y}$ gases follows the resistance-in-series scheme of Wesely (1989) as implemented in GEOS-Chem by Wang et al. (1998). We also add to the model two SSA alkalinity tracers in the fine and coarse modes and retain the inert SSA tracer to derive local concentrations of non-volatile SSA cations (Sect. 2.3). SSA de-bromination by oxidation of $\mathrm{Br}^{-}$as described by Schmidt et al. (2016) was included only as an option in standard version 11-02d of GEOS-Chem because of concern over excessive MBL BrO (Sherwen et al., 2016b). However, Zhu et al. (2018) show that it in fact allows a successful simulation of MBL $\mathrm{BrO}$ when one accounts for new losses in the standard model from aqueous-phase oxidation of $\mathrm{SO}_{2}$ by $\mathrm{HOBr}$ (Chen et al., 2017) and oxidation of marine acetaldehyde by $\mathrm{Br}$ atoms (Millet et al., 2010). We include SSA de-bromination in this work.

We present a 1-year global simulation for 2016 driven by GEOS-FP (forward processing) assimilated meteorological fields from the NASA Global Modeling and Assimilation office (GMAO) with native horizontal resolution of $0.25^{\circ} \times 0.3125^{\circ}$ and 72 vertical levels from the surface to the mesosphere. Our simulation is conducted at $4^{\circ} \times 5^{\circ}$ horizontal resolution and meteorological fields are conservatively regridded for that purpose. Stratospheric chemistry is represented using 3-D monthly mean production rates and loss rate constants from a fully coupled stratosphere-troposphere GEOS-Chem simulation (Murray et al., 2012; Eastham et al., 2014).

\subsection{Sources of chlorine}

Table 1 lists the global sources and sinks of tropospheric gasphase inorganic chlorine $\left(\mathrm{Cl}_{y}\right)$ and reactive chlorine $\left(\mathrm{Cl}^{*}\right)$ in our model. The main source is mobilization of $\mathrm{Cl}^{-}$from SSA. SSA emission is computed locally in GEOS-Chem separately for fine and coarse modes as the integrals of the size-dependent source function over two size bins, fine (0.2$1 \mu \mathrm{m}$ diameter) and coarse (1-8 $\mu \mathrm{m}$ diameter). The source function depends on wind speed and sea surface temperature (Jaeglé et al., 2011). We obtain a global SSA source of $3230 \mathrm{Tg} \mathrm{a}^{-1}$ for 2016 , corresponding to $1780 \mathrm{Tg} \mathrm{a}^{-1} \mathrm{Cl}^{-}$(assuming fresh SSA to be $55.05 \% \mathrm{Cl}^{-}$by mass (Lewis and Schwartz, 2014), of which $16 \%$ is in the fine mode and $84 \%$ is in the coarse mode. Only $64 \mathrm{Tg} \mathrm{Cl}^{-} \mathrm{a}^{-1}(3.6 \%)$ is mobilized to $\mathrm{Cl}_{y}$ by acid displacement and other heterogeneous reactions, while the rest is deposited. A total of $42 \%$ of the mobilization is from fine SSA and $58 \%$ is from coarse SSA. Details of this mobilization are in Sect. 2.3 and 2.4. About $80 \%$ of the mobilization is by acid displacement to $\mathrm{HCl}$, which is in turn efficiently deposited. Only $19 \%$ of $\mathrm{HCl}$ is further mobilized to $\mathrm{Cl}^{*}$ by reaction with $\mathrm{OH}$ to drive chlorine radical chemistry. Direct generation of $\mathrm{Cl}^{*}$ from SSA through heterogeneous chemistry provides a $\mathrm{Cl}^{*}$ source of comparable magnitude to $\mathrm{HCl}+\mathrm{OH}$, with dominant contri-
Table 1. Global sources and sinks of gas-phase inorganic $\left(\mathrm{Cl}_{y}\right)$ and reactive $\left(\mathrm{Cl}^{*}\right)$ tropospheric chlorine ${ }^{\mathrm{a}}$.

\begin{tabular}{|c|c|c|}
\hline & $\mathrm{Cl}_{y}\left(\mathrm{GgCla}^{-1}\right)$ & $\mathrm{Cl}^{*}\left(\mathrm{Gg} \mathrm{Cla}^{-1}\right)$ \\
\hline Total source & 75200 & 25000 \\
\hline Sea Salt & 63900 & 11900 \\
\hline Acid displacement ${ }^{\mathrm{b}}$ & 52000 & - \\
\hline $\mathrm{HOBr}+\mathrm{Cl}^{-}$ & 8590 & 8590 \\
\hline $\mathrm{N}_{2} \mathrm{O}_{5}+\mathrm{Cl}^{-}$ & 1810 & 1810 \\
\hline $\mathrm{HOI}, \mathrm{IONO}_{x}^{\mathrm{c}}+\mathrm{Cl}^{-}$ & 641 & 641 \\
\hline $\mathrm{ClNO}_{2}+\mathrm{Cl}^{-}$ & 327 & 327 \\
\hline $\mathrm{OH}+\mathrm{Cl}^{-}$ & 403 & 403 \\
\hline $\mathrm{ClNO}_{3}+\mathrm{Cl}^{-}$ & 64 & 64 \\
\hline $\mathrm{HOCl}+\mathrm{Cl}^{-}$ & 61 & 61 \\
\hline $\mathrm{HCl}+\mathrm{OH}$ & - & 9720 \\
\hline Organochlorines & 3320 & 3300 \\
\hline $\mathrm{CH}_{3} \mathrm{Cl}+\mathrm{OH}^{\mathrm{d}}$ & 2200 & 2180 \\
\hline $\mathrm{CH}_{2} \mathrm{Cl}_{2}+\mathrm{OH}$ & 780 & 780 \\
\hline $\mathrm{CHCl}_{3}+\mathrm{OH}$ & 298 & 298 \\
\hline $\mathrm{CH}_{2} \mathrm{ICl}+\mathrm{OH}$ & 46 & 46 \\
\hline Stratosphere ${ }^{\mathrm{e}}$ & 380 & 64 \\
\hline Anthropogenic $\mathrm{HCl}^{\mathrm{f}}$ & $(6660)$ & - \\
\hline Open fires & 7640 & - \\
\hline Total sink & 75200 & 25000 \\
\hline Deposition & 71400 & 346 \\
\hline Dry & 35200 & 170 \\
\hline Wet & 36200 & 176 \\
\hline Uptake by alkaline SSA & 3800 & - \\
\hline Conversion to $\mathrm{HCl}^{\mathrm{g}}$ & - & 24600 \\
\hline Tropospheric mass $(\mathrm{Gg})$ & 316 & 12 \\
\hline Lifetime (h) & 37 & 3.8 \\
\hline
\end{tabular}

a Annual totals for 2016 computed from GEOS-Chem. Gas-phase inorganic chlorine is defined as $\mathrm{Cl}_{y} \equiv \mathrm{Cl}+2 \times \mathrm{Cl}_{2}+2 \times \mathrm{Cl}_{2} \mathrm{O}_{2}+\mathrm{ClNO}_{2}+\mathrm{ClNO}_{3}+\mathrm{ClO}+\mathrm{ClOO}$ $+\mathrm{OClO}+\mathrm{BrCl}+\mathrm{ICl}+\mathrm{HOCl}+\mathrm{HCl}$. Reactive chlorine is defined as $\mathrm{Cl}^{*} \equiv \mathrm{Cl}_{y}-\mathrm{HCl}$. Thus the source of $\mathrm{HCl}$ can be inferred from the Table entries as $\mathrm{Cl}_{y}-\mathrm{Cl}^{*}$. The definition of $\mathrm{Cl}_{y}$ excludes aerosol $\mathrm{Cl}^{-}$, which has a very large sea salt source of

$1780 \mathrm{Tg} \mathrm{Cl} \mathrm{a}^{-1}$ but is mainly removed by deposition, $\mathrm{HCl}$ is the dominant component of $\mathrm{Cl}_{y}$ but is also mostly removed by deposition. Reactive chlorine $\mathrm{Cl}^{*}$ is the

chemical family principally involved in radical cycling. ${ }^{b}$ Net production minus loss of $\mathrm{HCl}$ from acid aerosol displacement by $\mathrm{HNO}_{3}$ and $\mathrm{H}_{2} \mathrm{SO}_{4}$ computed as thermodynamic equilibrium. ${ }^{\mathrm{c}} \mathrm{IONO}_{x} \equiv \mathrm{IONO}+\mathrm{IONO}^{\mathrm{d}}{ }^{\text {The source from }}$ $\mathrm{CH}_{3} \mathrm{Cl}+\mathrm{Cl}$ is not shown since it contributes $<1 \%$ of $\mathrm{CH}_{3} \mathrm{Cl}$ oxidation. Same for other organochlorines. ${ }^{\mathrm{e}}$ Net stratospheric input to the troposphere. ${ }^{\mathrm{f}} \mathrm{Coal}$ combustion, waste incineration, and industrial activities. These emissions are only included in a sensitivity simulation (see Sects. 2.2 and 4.2 for details) and are therefore listed here in parentheses. Emissions of anthropogenic fugitive dust are estimated as less than $390 \mathrm{Gg} \mathrm{a}^{-1}$ (Sect. 2.2) and are not included in the model. $\mathrm{g}$ From reactions of $\mathrm{Cl}$ atoms (see Fig. 1).

butions from $\mathrm{HOBr}+\mathrm{Cl}^{-}$and $\mathrm{N}_{2} \mathrm{O}_{5}+\mathrm{Cl}^{-}$(the latter in polluted high- $\mathrm{NO}_{x}$ environments).

$\mathrm{Cl}^{*}$ can also be produced in the model by atmospheric degradation of the organochlorine gases $\mathrm{CH}_{3} \mathrm{Cl}, \mathrm{CH}_{2} \mathrm{Cl}_{2}$, $\mathrm{CHCl}_{3}$, and $\mathrm{CH}_{2} \mathrm{ICl}$. These gases are mainly of biogenic marine origin, with the exception of $\mathrm{CH}_{2} \mathrm{Cl}_{2}$, which has a large industrial solvent source (Simmonds et al., 2006). Mean tropospheric lifetimes are 520 days for $\mathrm{CH}_{3} \mathrm{Cl}, 280$ days for $\mathrm{CH}_{2} \mathrm{Cl}_{2}, 260$ days for $\mathrm{CHCl}_{3}$, and 0.4 days for $\mathrm{CH}_{2} \mathrm{ICl}$. Emissions of $\mathrm{CH}_{3} \mathrm{Cl}, \mathrm{CH}_{2} \mathrm{Cl}_{2}$, and $\mathrm{CHCl}_{3}$ are implicitly 
treated in the model by specifying monthly mean surface air boundary conditions in five latitude bands $(60-90,30$ 60 , and $0-30^{\circ} \mathrm{N}, 0-30$, and $30-90^{\circ} \mathrm{S}$ ) from AGAGE observations (Prinn et al., 2018). Emission of $\mathrm{CH}_{2} \mathrm{ICl}$ is from Ordóñez et al. (2012), as described by Sherwen et al. (2016a). Tropospheric oxidation of hydrochlorofluorocarbons (HCFCs) is neglected as a source of $\mathrm{Cl}^{*}$ because it is small compared to the other organochlorines. The stratospheric source of $\mathrm{Cl}_{y}$ from chlorofluorocarbons (CFCs), HCFCs, and $\mathrm{CCl}_{4}$ is included in the model on the basis of the Eastham et al. (2014) GEOS-Chem stratospheric simulation as described in Sect. 2.1. Tropospheric organochlorines give a global $\mathrm{Cl}^{*}$ source of $3.3 \mathrm{Tg} \mathrm{Cla}^{-1}$ in Table 1 , smaller than that from heterogeneous $\mathrm{SSA} \mathrm{Cl}^{-}$reactions $\left(11.9 \mathrm{Tg} \mathrm{Cla}^{-1}\right)$ or oxidation of $\mathrm{HCl}$ by $\mathrm{OH}\left(9.7 \mathrm{Tg} \mathrm{Cla}^{-1}\right)$. The stratosphere is a minor global source of tropospheric $\mathrm{Cl}^{*}\left(0.06 \mathrm{Tg} \mathrm{Cl} \mathrm{a}^{-1}\right)$ although it could be important in the upper troposphere (Schmidt et al., 2016).

We also include primary $\mathrm{HCl}$ emissions from open fires. We apply the emission factors of $\left(\mathrm{HCl}+\mathrm{Cl}^{-}\right)$from Lobert et al. (1999) for different vegetation types to the GFED4 (Global Fire Emissions Database) biomass burned inventory (van der Werf et al., 2010; Giglio et al., 2013), resulting in a global source of $7.6 \mathrm{Tg} \mathrm{Cl} \mathrm{a}^{-1}$ emitted as $\mathrm{HCl}$.

Anthropogenic sources of $\mathrm{HCl}$ include coal combustion, waste incineration, and industrial activities. The only global emission inventory is that of McCulloch et al. (1999), which gives a total of $6.7 \mathrm{Tg} \mathrm{Cla}^{-1}$. As shown in Sect. 4.2, we find that this greatly overestimates atmospheric observations of $\mathrm{HCl}$ over the US. National inventories of $\mathrm{HCl}$ from coal combustion available for China ( $236 \mathrm{Gg} \mathrm{Cla}^{-1}$ in 2012; Liu et al., 2018) and the US (69 $\mathrm{Gg} \mathrm{Cla}^{-1}$ in 2014; US EPA, 2018) are respectively 6 and 7 times lower than estimates of McCulloch et al. (1999) for those countries. We therefore choose not to include anthropogenic $\mathrm{HCl}$ emissions in our standard simulation, as they are small in any case from a global budget perspective. We show in Sect. 4.2 that we can account for $\mathrm{HCl}$ observations in continental air largely on the basis of the $\mathrm{SSA} \mathrm{Cl}^{-}$source. We also do not consider $\mathrm{Cl}^{*}$ generation from snow/ice surfaces, which could be important in the Arctic spring MBL (Liao et al., 2014) but is highly uncertain and would only affect a small atmospheric domain.

We do not include the anthropogenic $\mathrm{Cl}^{-}$source from fugitive dust, although it might be important in contributing to chloride levels in continental surface air (Sarwar et al., 2012). The global source of anthropogenic fugitive dust is estimated to be less than $13 \mathrm{Tg} \mathrm{a}^{-1}$ (Philip et al., 2017), of which $0.3 \%$ by mass is estimated to be chloride (Reff et al., 2009). This corresponds to a chloride source of less than $0.39 \mathrm{Tg} \mathrm{Cl} \mathrm{a}^{-1}$, negligible on a global scale.

\section{$2.3 \mathrm{HCl} / \mathrm{Cl}^{-}$acid displacement thermodynamics}

SSA $\mathrm{Cl}^{-}$can be displaced to $\mathrm{HCl}$ by strong acids $\left(\mathrm{H}_{2} \mathrm{SO}_{4}\right.$, $\mathrm{HNO}_{3}$ ) once the SSA is sufficiently aged that its initial sup- ply of alkalinity $\left(\equiv \mathrm{HCO}_{3}^{-}+2 \times \mathrm{CO}_{3}^{2-}\right.$ ) has been exhausted. The acid displacement is described by

$\mathrm{Cl}^{-}+\mathrm{HNO}_{3} \rightleftarrows \mathrm{HCl}+\mathrm{NO}_{3}^{-}$,

$\mathrm{Cl}^{-}+\mathrm{H}_{2} \mathrm{SO}_{4} \rightleftarrows \mathrm{HCl}+\mathrm{HSO}_{4}^{-}$,

with equilibrium constants from Fountoukis and Nenes (2007). Reaction (R1) must be treated as an equilibrium because $\mathrm{HNO}_{3}$ and $\mathrm{HCl}$ have comparable effective Henry's law constants. $\mathrm{H}_{2} \mathrm{SO}_{4}$ has a much lower vapor pressure so that Reaction (R2) fully displaces $\mathrm{HCl}$. Additional displacement of $\mathrm{HCl}$ by $\mathrm{HSO}_{4}^{-}$does not take place because $\mathrm{HSO}_{4}^{-}$is a much weaker acid than $\mathrm{HCl}$ (Jacob et al., 1985).

Alkalinity initially prevents any acid displacement in freshly emitted SSA. Alkalinity is emitted as 0.07 mol equivalents $\mathrm{kg}^{-1}$ of dry SSA (Gurciullo et al., 1999) and is transported in the model as two separate tracers for fine and coarse SSA. It is consumed over time by uptake of acids $\left(\mathrm{SO}_{2}, \mathrm{H}_{2} \mathrm{SO}_{4}, \mathrm{HNO}_{3}\right.$, and $\left.\mathrm{HCl}\right)$ as described by Alexander et al. (2005), and once fully consumed it is set to zero (titration). The SSA is then diagnosed as acidified, enabling acid displacement by Reactions (R1)-(R2). In our simulation, alkalinity is titrated everywhere shortly after emission except in some areas of the Southern Ocean, which is consistent with the model results of Alexander et al. (2005) and Kasibhatla et al. (2018).

Observations in the MBL indicate that fine SSA is usually internally mixed with sulfate-nitrate-ammonium (SNA) aerosols while coarse SSA is externally mixed (Fridlind and Jacobson, 2000; Dasgupta et al., 2007). Acid displacement for the acidified fine SSA is thus computed by adding $\mathrm{HCl} / \mathrm{Cl}^{-}$to the SNA thermodynamics. The local thermodynamic gas-aerosol equilibrium for the resulting $\mathrm{H}_{2} \mathrm{SO}_{4}-\mathrm{HCl}-\mathrm{HNO}_{3}-\mathrm{NH}_{3}-\mathrm{NVC}$ system is calculated with ISORROPIA II (Fountoukis and Nenes, 2007). The calculation is performed assuming an aqueous aerosol even if relative humidity is below the deliquescence point (metastable state). NVCs (non-volatile cations) describe the sum of cations emitted as SSA and is treated in ISORROPIA II using $\mathrm{Na}^{+}$as proxy. Here NVCs are emitted as $16.4 \mathrm{~mol} \mathrm{~kg}^{-1}$ of dry SSA to balance the emission of SSA anions including $\mathrm{Cl}^{-}$, alkalinity, and sea salt sulfate. The NVC concentration is determined locally from the mass concentration of the inert SSA tracer.

Acid displacement for acidified coarse SSA is assumed to be driven by uptake of strong acids from the gas phase, mainly $\mathrm{HNO}_{3}$ (Kasibhatla et al., 2018). The ISORROPIA II calculation is conducted with two gas species $\left(\mathrm{HNO}_{3}\right.$ and $\mathrm{HCl})$ and four aerosol species $\left(\mathrm{NVC}, \mathrm{Cl}^{-}, \mathrm{SO}_{4}^{2-}\right.$, and $\mathrm{NO}_{3}^{-}$). Here the sulfate includes only the emitted sea salt component and that produced by heterogeneous $\mathrm{SO}_{2}$ oxidation in coarse SSA (Alexander et al., 2005). In the case of coarse aerosols, there may be significant mass transfer limitation to reaching gas-aerosol thermodynamic partitioning (Meng 
and Seinfeld, 1996). To account for this limitation, the concentrations are adjusted after the ISORROPIA II calculation following the dynamic method of Pilinis et al. (2000). This two-step thermodynamics approach has been used in previous studies (Koo et al., 2003; Kelly et al., 2010).

\subsection{Heterogeneous chemistry of $\mathrm{Cl}^{-}$}

Table 2 lists the heterogeneous reactions of $\mathrm{Cl}^{-}$other than acid displacement. The loss rate of a gas species $X$ due to reaction with $\mathrm{Cl}^{-}$is calculated following Jacob (2000):

$$
\frac{\mathrm{d} n_{X}}{\mathrm{~d} t}=-\left(\frac{r}{D_{\mathrm{g}}}+\frac{4}{c \gamma\left(\left[\mathrm{Cl}^{-}\right]\right)}\right)^{-1} A n_{X} .
$$

Here $n_{X}$ is the number density of species $X$ (molecules of $X$ per unit volume of air), $A$ is the aerosol or cloud surface area concentration per unit volume of air, $r$ is the effective particle radius, $D_{\mathrm{g}}$ is the gas-phase molecular diffusion coefficient of $X, c$ is the average gas-phase thermal velocity of $X$, and $\gamma$ is the reactive uptake coefficient, which is a function of the aqueous-phase molar $\mathrm{Cl}^{-}$concentration $\left[\mathrm{Cl}^{-}\right]$(moles of $\mathrm{Cl}^{-}$per liter of water). Values of $\gamma$ in Table 2 are mostly from recommendations by the International Union of Pure and Applied Chemistry (IUPAC) (Ammann et al., 2013).

The heterogeneous reactions take place in both clearair aerosol and clouds. The GEOS-FP input meteorological data include cloud fraction and liquid/ice water content for every grid cell. Concentrations per cubic centimeter of air of aerosol-phase species (including fine and coarse $\mathrm{Cl}^{-}$and $\mathrm{Br}^{-}$) within a grid cell are partitioned between clear air and cloud as determined by the cloud fraction. Clear-air aqueous-phase concentrations for use in calculating heterogeneous reaction rates are derived from the relativehumidity-dependent liquid water contents of fine and coarse SSA using aerosol hygroscopic growth factors from the Global Aerosol Database (GADS, Koepke, 1997) with an update by Lewis and Schwartz (2006). In-cloud aqueous-phase concentrations are derived using liquid and ice water content from the GEOS-FP meteorological data. Values of $r$ in Eq. (1) are specified as relative-humidity-dependent effective radii for the different clear-air aerosol components (Martin et al., 2003), and are set to $10 \mu \mathrm{m}$ for cloud droplets and $75 \mu \mathrm{m}$ for ice particles. These effective radii are also used to infer the area concentrations $A$ on the basis of the mass concentrations. Heterogeneous chemistry in ice clouds is restricted to the unfrozen layer coating the ice crystal, which is assumed to be $1 \%$ of the ice crystal radius (Schmidt et al., 2016).

The heterogeneous uptake of $\mathrm{HOBr}, \mathrm{HOCl}$, and $\mathrm{ClNO}_{2}$ as well as further aqueous-phase reaction with $\mathrm{Cl}^{-}$in Table 2 are $\mathrm{pH}$ dependent, with a higher efficiency in acidic solutions (Fickert et al., 1999; Roberts et al., 2008; Abbatt et al., 2012). They are considered only when SSA alkalinity has been titrated, and $\mathrm{ClNO}_{2}+\mathrm{Cl}^{-}$further requires $\mathrm{pH}<2$, following laboratory results presented in Roberts et al. (2008). The pH of chloride-containing fine aerosol after alkalinity has been titrated is calculated by ISORROPIA II. Liquid cloud water $\mathrm{pH}$ is calculated in GEOS-Chem following Alexander et al. (2012), with update to include $\mathrm{Cl}^{-}$and NVC. Coarse-mode SSA and ice cloud $\mathrm{pH}$ are assumed to be 5 and 4.5, respectively (Schmidt et al., 2016).

\section{Global budget and distribution of tropospheric chlorine}

Figure 1 describes the global budget and cycling of tropospheric inorganic chlorine in GEOS-Chem. The dominant source of $\mathrm{Cl}_{y}$ is acid displacement from SSA. The global rate of $\mathrm{Cl}_{y}$ generation from acid displacement is $52 \mathrm{Tg} \mathrm{Cla}^{-1}$, close to the observationally based estimate of $50 \mathrm{Tg} \mathrm{Cla}^{-1}$ by Graedel and Keene (1995) and lower than the model estimate of $90 \mathrm{Tg} \mathrm{Cl} \mathrm{a}^{-1}$ from Hossaini et al. (2016), who treated displacement of $\mathrm{Cl}^{-}$by $\mathrm{HNO}_{3}$ as an irreversible rather than thermodynamic equilibrium process. $\mathrm{HCl}$ is the largest reservoir of $\mathrm{Cl}_{y}$ in the troposphere, with a global mean tropospheric mixing ratio of $60 \mathrm{ppt}\left(\mathrm{ppt} \equiv \mathrm{pmol} \mathrm{mol}^{-1}\right)$.

Acid displacement generates $\mathrm{Cl}_{y}$ as $\mathrm{HCl}$, which is mostly removed by deposition. Broader effects of chlorine on tropospheric chemistry take place through the cycling of radicals originating from production of reactive chlorine $\mathrm{Cl}^{*} \equiv$ $\mathrm{Cl}_{y}-\mathrm{HCl}$. $\mathrm{HCl}$ contributes $9.7 \mathrm{Tg} \mathrm{Cla}^{-1}$ to $\mathrm{Cl}^{*}$ through the reaction between $\mathrm{HCl}$ and $\mathrm{OH}$. In addition to this source, $\mathrm{Cl}^{-}$ provides a $\mathrm{Cl}^{*}$ source of $12 \mathrm{Tg} \mathrm{Cl} \mathrm{a}^{-1}$ through heterogeneous reactions with principal contributions from $\mathrm{HOBr}+\mathrm{Cl}^{-}$ $\left(8.6 \mathrm{Tg} \mathrm{Cla}^{-1}\right)$ and $\mathrm{N}_{2} \mathrm{O}_{5}+\mathrm{Cl}^{-}\left(1.8 \mathrm{Tg} \mathrm{Cl} \mathrm{a}^{-1}\right)$. This heterogeneous source of $12 \mathrm{Tg} \mathrm{Cla}^{-1}$ is much higher than previous estimates of $5.6 \mathrm{Tg} \mathrm{Cla}^{-1}$ (Hossaini et al., 2016) and 6.1 $\mathrm{Tg} \mathrm{Cla}^{-1}$ (Schmidt et al., 2016). Schmidt et al. (2016) only considered the $\mathrm{HOBr}+\mathrm{Cl}^{-}$reaction. Production of the chlorine radicals $\mathrm{Cl}$ and $\mathrm{ClO}$ is by the $\mathrm{HCl}+\mathrm{OH}$ reaction $(45 \%)$ and by photolysis of $\mathrm{BrCl}(40 \%), \mathrm{ClNO}_{2}(8 \%), \mathrm{Cl}_{2}$ (4\%), and $\mathrm{ICl}(2 \%)$. Loss of $\mathrm{Cl}^{*}$ is mainly through the reaction of $\mathrm{Cl}$ with methane ( $46 \%$ ) and other organic compounds $\left(\mathrm{CH}_{3} \mathrm{OH} 15 \%, \mathrm{CH}_{3} \mathrm{OOH} 11 \%, \mathrm{C}_{2} \mathrm{H}_{6} 8 \%\right.$, higher alkanes $8 \%$, and $\mathrm{CH}_{2} \mathrm{O} 7 \%$ ).

Conversion of $\mathrm{Cl}$ to $\mathrm{ClO}^{*}$ drives some cycling of chlorine radicals, but the associated chain length versus $\mathrm{Cl}^{*}$ loss is short $\left(4.1 \times 10^{4} / 2.5 \times 10^{4}=1.6\right)$. Conversion of $\mathrm{Cl}$ to $\mathrm{ClO}$ is mainly by reaction with ozone ( $98 \%)$, while conversion of $\mathrm{ClO}$ back to $\mathrm{Cl}$ is mostly by reaction with $\mathrm{NO}(72 \%)$, driving a null cycle as $\mathrm{NO}_{2}$ photolyzes to regenerate $\mathrm{NO}$ and ozone.

Figure 2 shows the annual mean global distributions of $\mathrm{HCl}$ mixing ratios and $\mathrm{Cl}$ atom concentrations. The mixing ratio of $\mathrm{HCl}$ decreases from the surface to the middle troposphere, reflecting the SSA source, and then increases again in the upper troposphere where it is supplied by transport from the stratosphere and has a long lifetime due to lack of scavenging. Remarkably, $\mathrm{Cl}$ atom concentrations show little decrease with altitude, contrary to the common assumption 
Table 2. Heterogeneous reactions of $\mathrm{Cl}^{-}$and reactive uptake coefficients $(\gamma)^{\mathrm{a}}$.

\begin{tabular}{|c|c|c|c|}
\hline & Reaction & Reactive uptake coefficient $(\gamma)$ & Footnote \\
\hline R3 & $\begin{array}{l}\mathrm{N}_{2} \mathrm{O}_{5}+\varphi \mathrm{Cl}^{-}+(1-\varphi) \mathrm{H}_{2} \mathrm{O} \rightarrow \varphi \mathrm{ClNO}_{2}+ \\
(2-\varphi) \mathrm{NO}_{3}^{-}+2(1-\varphi) \mathrm{H}^{+}\end{array}$ & $\begin{array}{l}\gamma=B k_{2 f}^{\prime}\left(1-\frac{1}{\left(\frac{k_{3}\left[\mathrm{H}_{2} \mathrm{O}\right]}{k_{2 b}\left[\mathrm{NO}_{3}^{-}\right]}\right)+1+\left(\frac{k_{4}\left[\mathrm{Cl}^{-}\right]}{k_{2 b}\left[\mathrm{NO}_{3}^{-}\right]}\right)}\right) \\
k_{2 f}^{\prime}=\beta\left(1-e^{-\delta\left[\mathrm{H}_{2} \mathrm{O}\right]}\right) ; \varphi=\left(\frac{k_{2}\left[\mathrm{H}_{2} \mathrm{O}\right]}{k_{3}\left[\mathrm{Cl}^{-}\right]}+1\right)^{-1} \\
B=3.2 \times 10^{-8} \mathrm{~s} ; k_{3} / k_{2}=450 \\
\beta=1.15 \times 10^{6} \mathrm{~s}^{-1} ; \delta=0.13 \mathrm{M}^{-1} \\
k_{3} / k_{2 b}=0.06 ; k_{4} / k_{2 b}=29\end{array}$ & $\mathrm{~b}$ \\
\hline $\mathrm{R} 4$ & $\mathrm{OH}+\mathrm{Cl}^{-} \rightarrow 0.5 \mathrm{Cl}_{2}+\mathrm{OH}^{-}$ & $\gamma=0.04\left[\mathrm{Cl}^{-}\right]$ & $\mathrm{c}$ \\
\hline R5 & $\mathrm{HOBr}+\mathrm{Cl}^{-}+\mathrm{H}^{+} \rightarrow \mathrm{BrCl}+\mathrm{H}_{2} \mathrm{O}$ & $\begin{array}{l}\gamma=\left(\frac{1}{\Gamma_{b}}+\frac{1}{\alpha_{b}}\right)^{-1} \\
\Gamma_{b}=4 H_{\mathrm{HOBr}} R T I_{r} k_{b}\left[\mathrm{Cl}^{-}\right]\left[\mathrm{H}^{+}\right] f\left(r, l_{r}\right) / c \\
l_{r}=\sqrt{D_{l} /\left(k_{b}\left[\mathrm{Cl}^{-}\right]\left[\mathrm{H}^{+}\right]\right)} ; \alpha_{b}=0.6 \\
k_{b}=2.3 \times 10^{10} \mathrm{M}^{-2} \mathrm{~s}^{-1} ; D_{l}=1.4 \times 10^{-5} \mathrm{~cm}^{2} \mathrm{~s}^{-1}\end{array}$ & $\mathrm{~d}$ \\
\hline R6 & $\mathrm{ClNO}_{3}+\mathrm{Cl}^{-} \rightarrow \mathrm{Cl}_{2}+\mathrm{NO}_{3}^{-}$ & $\gamma=0.0244$ & $\mathrm{e}$ \\
\hline R7 & $\mathrm{ClNO}_{2}+\mathrm{Cl}^{-} \rightarrow \mathrm{NO}_{2}^{-}+\mathrm{Cl}_{2}$ & $\begin{array}{l}\gamma=\left(\frac{1}{\Gamma_{b}}+\frac{1}{\alpha_{b}}\right)^{-1}(\mathrm{pH}<2), \gamma=0(\mathrm{pH}>2) \\
\Gamma_{b}=4 H_{\mathrm{ClNO}_{2}} R T I_{r} k^{I I}\left[\mathrm{Cl}^{-}\right] f\left(r, l_{r}\right) / c \\
l_{r}=\sqrt{D_{l} /\left(k^{I I}\left[\mathrm{Cl}^{-}\right]\right)} ; \alpha_{b}=0.01 \\
k^{I I}=10^{7} \mathrm{M}^{-2} \mathrm{~s}^{-1} ; D_{l}=1 \times 10^{-5} \mathrm{~cm}^{2} \mathrm{~s}^{-1}\end{array}$ & \\
\hline $\mathrm{R} 8$ & $\mathrm{ClNO}_{2}+\mathrm{Br}^{-} \rightarrow \mathrm{NO}_{2}^{-}+\mathrm{BrCl}$ & $\begin{array}{l}\gamma=\left(\frac{1}{\Gamma_{b}}+\frac{1}{\alpha_{b}}\right)^{-1} \\
\Gamma_{b}=4 H_{\mathrm{ClNO}_{2}} R T I_{r} k^{I I}\left[\mathrm{Br}^{-}\right] f\left(r, l_{r}\right) / c \\
l_{r}=\sqrt{D_{l} /\left(k^{I I}\left[\mathrm{Br}^{-}\right]\right)} ; \alpha_{b}=0.01 \\
H_{\mathrm{ClNO}_{2}}{ }^{2} D_{l} k^{I I}=0.101 \mathrm{M} \mathrm{cm}^{2} \mathrm{~s}^{-2}\end{array}$ & \\
\hline R9 & $\mathrm{HOCl}+\mathrm{Cl}^{-}+\mathrm{H}^{+} \rightarrow \mathrm{Cl}_{2}+\mathrm{H}_{2} \mathrm{O}$ & $\begin{array}{l}\gamma=\min \left(\left(\frac{1}{\Gamma_{b}}+\frac{1}{\alpha_{b}}\right)^{-1}, 2 \times 10^{-4}\right) \\
\Gamma_{b}=4 H_{\mathrm{HOCl}} R T I_{r} k_{t}\left[\mathrm{Cl}^{-}\right]\left[\mathrm{H}^{+}\right] f\left(r, l_{r}\right) / c \\
l_{r}=\sqrt{D_{l} /\left(k_{t}\left[\mathrm{Cl}^{-}\right]\left[\mathrm{H}^{+}\right]\right) ; \alpha_{b}=0.8} \\
k_{t}=1.5 \times 10^{4} \mathrm{M}^{-2} \mathrm{~s}^{-1} ; D_{l}=2 \times 10^{-5} \mathrm{~cm}^{2} \mathrm{~s}^{-1}\end{array}$ & \\
\hline $\mathrm{R} 10$ & $\mathrm{NO}_{3}+\mathrm{Cl}^{-} \rightarrow \mathrm{NO}_{3}^{-}+\mathrm{Cl}^{-}$ & $\begin{array}{l}\gamma=\left(\frac{1}{\Gamma_{b}}+\frac{1}{\alpha_{b}}\right)^{-1} \\
\Gamma_{b}=4 H_{\mathrm{NO}_{3}} R T I_{r} k^{\prime}\left[\mathrm{Cl}^{-}\right] f\left(r, l_{r}\right) / c \\
l_{r}=\sqrt{D_{l} /\left(k^{\prime}\left[\mathrm{Cl}^{-}\right]\right)} ; \alpha_{b}=0.013 \\
k^{\prime}=2.76 \times 10^{6} \mathrm{M}^{-2} \mathrm{~s}^{-1} ; D_{l}=1 \times 10^{-5} \mathrm{~cm}^{2} \mathrm{~s}^{-1}\end{array}$ & \\
\hline $\mathrm{R} 11$ & $\mathrm{IONO}_{2}+\mathrm{Cl}^{-} \rightarrow \mathrm{ICl}+\mathrm{NO}_{3}^{-}$ & $\gamma=8.5 \times 10^{-3}$ & $\mathrm{f}$ \\
\hline $\mathrm{R} 12$ & $\mathrm{IONO}+\mathrm{Cl}^{-} \rightarrow \mathrm{ICl}+\mathrm{NO}_{2}^{-}$ & $\gamma=0.017$ & $\mathrm{f}$ \\
\hline $\mathrm{R} 13$ & $\mathrm{HOI}+\mathrm{Cl}^{-} \rightarrow \mathrm{ICl}+\mathrm{OH}^{-}$ & $\gamma=8.5 \times 10^{-3}$ & $\mathrm{f}$ \\
\hline
\end{tabular}

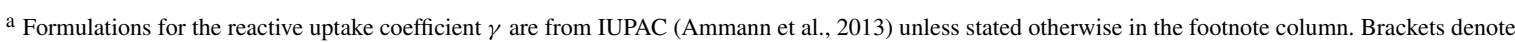
aqueous-phase concentrations in molarity (moles per liter of water). $R$ is the ideal gas constant. $c$ is the average gas-phase thermal velocity for the reactant with $\mathrm{Cl}^{-}$. The reactive uptake coefficient is used to calculate the reaction rate following Eq. (1). $f\left(r, l_{r}\right)=\operatorname{coth}\left(r / l_{r}\right)-\left(l_{r} / r\right)$ is a spherical correction to mass transfer for which $l_{r}$ is a reacto-diffusive length scale and $r$ is the radius of the aerosol particle or cloud droplet. ${ }^{\mathrm{b}}$ Bertram and Thornton (2009); Roberts et al. (2009). This parametrization is only applied for SNA and SSA aerosols. For $\mathrm{N}_{2} \mathrm{O}_{5}$ uptake on other aerosols, we assume $\varphi=0$ and follow Jaeglé et al. (2018). ${ }^{\mathrm{c}}$ Knipping and Dabdub (2002). ${ }^{\mathrm{d}} k_{b}$ is based on Liu and Margerum (2001). Reaction (R5) competes with the heterogeneous reactions HOBr $+\mathrm{Br}^{-}$ and $\mathrm{HOBr}+\mathrm{S}(\mathrm{IV})$ as given by Chen et al. (2017). The $\mathrm{BrCl}$ product may either volatilize or react with $\mathrm{Br}^{-}$to produce $\mathrm{Br}_{2}$ and return $\mathrm{Cl}^{-}$following Fickert et al. (1999), as described in Sect. 5.2. ${ }^{\mathrm{e}}$ Assumes that $\mathrm{Cl}^{-}$is present in excess so that $\gamma$ does not depend on [Cl$\left.{ }^{-}\right]$. However, $\mathrm{Reaction}$ (R6) competes with the heterogeneous reaction $\mathrm{ClNO}_{3}+\mathrm{Br}^{-}$as given by Schmidt et al. (2016), with the branching ratio determined by the relative rates. ${ }^{\mathrm{f}}$ These reactions are based on Sherwen et al. (2016a) and only take place in SSA. 


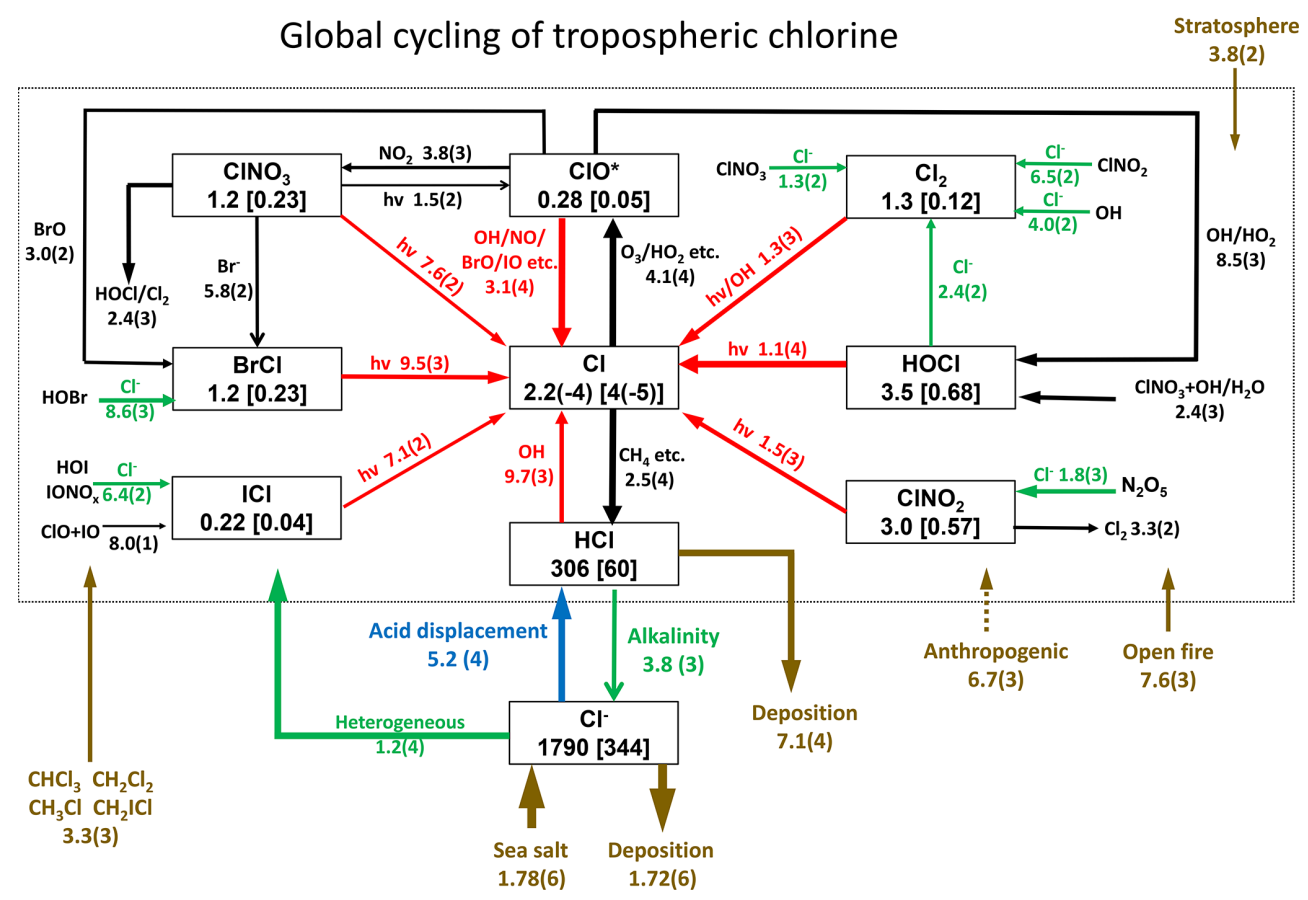

Figure 1. Global budget and cycling of tropospheric inorganic chlorine $\left(\mathrm{Cl}_{y}\right)$ in GEOS-Chem. The figure shows global annual mean rates $\left(\mathrm{Gg} \mathrm{Cla}^{-1}\right)$, masses $(\mathrm{Gg})$, and mixing ratios (ppt, in brackets) for simulation year 2016. Read 2.5(4) as $2.5 \times 10^{4}$. $\mathrm{ClO}^{*}$ stands for $\mathrm{ClO}+$ $\mathrm{OClO}+\mathrm{ClO}_{2}+2 \times \mathrm{Cl}_{2} \mathrm{O}_{2} ; 84 \%$ is present as $\mathrm{ClO}$. Reactions producing $\mathrm{Cl}$ atoms and related to $\mathrm{Cl}^{-}$heterogeneous chemistry are shown in red and green, respectively. The dotted box indicates the $\mathrm{Cl}_{y}$ family, and arrows into and out of that box represent general sources and sinks of $\mathrm{Cl}_{y}$. Reactions with the rate $<100 \mathrm{Gg} \mathrm{Cla}^{-1}$ are not shown. Anthropogenic emissions of $\mathrm{HCl}$ as indicated by a dashed line are only included in a sensitivity simulation (see Sects. 2.2 and 4.2 for details).

that tropospheric $\mathrm{Cl}$ atoms should be mainly confined to the MBL where the SSA source resides (Singh et al., 1996). We find that the effect of the SSA source is offset by the slower sink of $\mathrm{Cl}^{*}$ at higher altitudes due to the strong temperature dependence of the reactions between $\mathrm{Cl}$ atom and organic compounds. Transport of $\mathrm{HCl}$ and $\mathrm{Cl}^{*}$ from the stratosphere also contribute to the source of $\mathrm{Cl}$ atoms in the upper troposphere.

$\mathrm{HCl}$ mixing ratios in marine surface air are usually highest along polluted coastlines where the large sources of $\mathrm{HNO}_{3}$ and $\mathrm{H}_{2} \mathrm{SO}_{4}$ from anthropogenic $\mathrm{NO}_{x}$ and $\mathrm{SO}_{2}$ emissions drive acid displacement from SSA. By contrast, $\mathrm{HCl}$ mixing ratios over the Southern Ocean are low because of the low supply of acid gases. The distribution of $\mathrm{Cl}$ atoms in surface air reflects its sources from both $\mathrm{HCl}+\mathrm{OH}$ and the heterogeneous production of $\mathrm{Cl}^{*}$. The highest concentrations are in northern Europe due to production of $\mathrm{ClNO}_{2}$ from the $\mathrm{N}_{2} \mathrm{O}_{5}+\mathrm{Cl}^{-}$Reaction (R3). $\mathrm{Cl}$ atom concentrations in marine air are shifted poleward relative to $\mathrm{HCl}$ because of increasing bromine radical concentrations (Parrella et al., 2012), driving $\mathrm{BrCl}$ formation by the $\mathrm{HOBr}+\mathrm{Cl}^{-}$Reaction (R5).

Figure 3 shows the global mean vertical distributions of reactive chlorine species $\left(\mathrm{Cl}^{*}\right)$ in continental and marine air. Mean boundary layer mixing ratios are higher over land than over the ocean because of the $\mathrm{ClNO}_{2}$ source from
$\mathrm{N}_{2} \mathrm{O}_{5}+\mathrm{Cl}^{-}$in high- $\mathrm{NO}_{x}$ polluted air (Thornton et al., 2010). $\mathrm{ClNO}_{2}$ mixing ratios are much higher than in the Sherwen et al. (2016b) model, which restricted its production to SSA, reflecting the importance of $\mathrm{HCl}$ dissolved in SNA aerosol, which allows further transport inland. High mixing ratios of $\mathrm{ClNO}_{3}$ in the upper troposphere are due to transport from the stratosphere and inefficacy of the sinks from hydrolysis and heterogeneous chemistry. In the marine MBL we find comparable contributions from $\mathrm{HOCl}$ (mainly in daytime) and $\mathrm{Cl}_{2}$ and $\mathrm{ClNO}_{2}$ (mainly at night). The $\mathrm{BrCl}$ mixing ratio is much lower than in the previous model studies of Long et al. (2014) and Sherwen et al. (2016b), which had very large sources from the $\mathrm{HOBr}+\mathrm{Cl}^{-}$Reaction (R5). Our lower $\mathrm{BrCl}$ mixing ratio is due to competition from the $\mathrm{HOBr}+\mathrm{S}(\mathrm{IV})$ $\left(\mathrm{S}(\mathrm{IV}) \equiv \mathrm{HSO}_{3}^{-}+\mathrm{SO}_{3}^{2-}\right.$ ) reaction (Chen et al., 2017) and to oceanic VOC emissions (Millet et al., 2010), both of which act to depress bromine radical concentrations in the MBL (Zhu et al., 2018). Further discussion of the $\mathrm{BrCl}$ source is presented in Sect. 5.2.

\section{Comparison to observations}

Here we compare the model simulation for 2016 to observations for gas-phase chlorine and related species collected in different years, assuming interannual variability to be a mi- 


\section{Surface and zonal mean $\mathrm{HCl}$ mixing ratios and $\mathrm{Cl}$ atom concentrations}

(a)
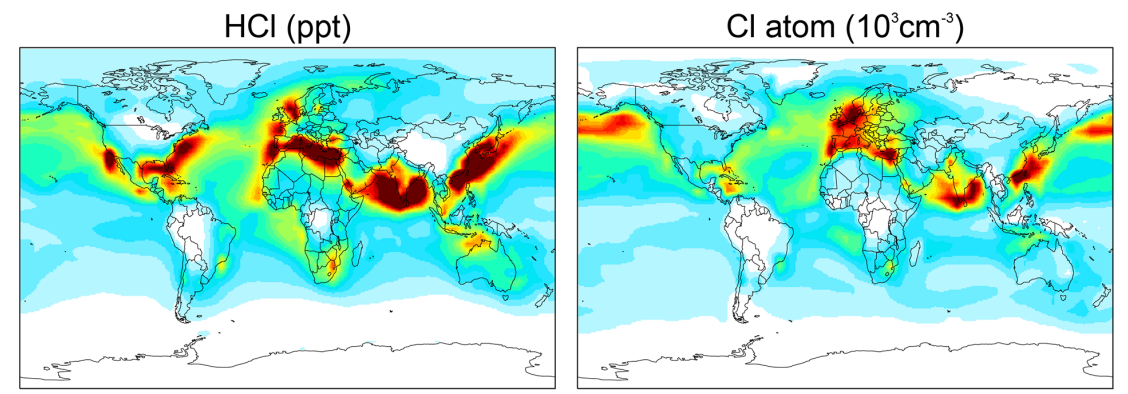

(b)
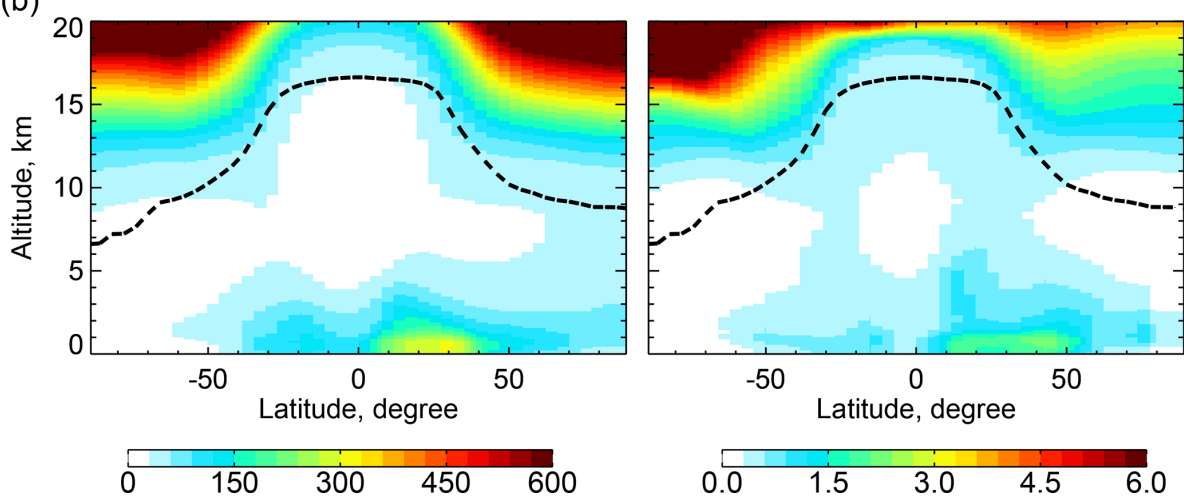

Figure 2. Global distributions of annual mean $\mathrm{HCl}$ mixing ratios and $\mathrm{Cl}$ atom concentrations in GEOS-Chem. Panel (a) shows surface air mixing ratios and concentrations. Panel (b) shows zonal mean mixing ratios and concentrations as a function of latitude and altitude. Dashed lines indicate the tropopause.
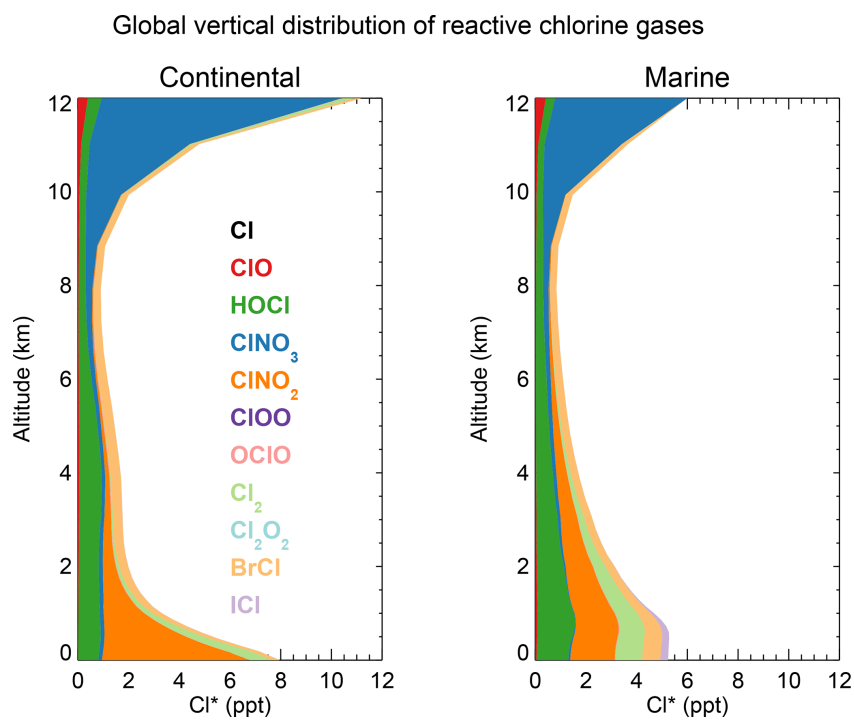

Figure 3. Global annual mean vertical distributions of reactive chlorine species $\left(\mathrm{Cl}^{*}\right)$ in GEOS-Chem for continental and marine air. Stratospheric conditions are excluded.

nor factor in model error. Previous evaluation of the GEOSChem sea salt source by Jaeglé et al. (2011) showed general skill in simulating SSA observations and we do not repeat this evaluation here. We also do not consider data affected by local anthropogenic sources because they would not be properly resolved at the $4^{\circ} \times 5^{\circ}$ grid resolution of our model.

\subsection{Surface air observations}

Table 3 compares our simulated $\mathrm{Cl}^{-}$SSA deficits to an ensemble of marine air observations compiled by Graedel and Keene (1995). The $\mathrm{Cl}^{-}$deficit is relative to seawater composition and provides an indicator of the mobilization of $\mathrm{Cl}^{-}$ through acid displacement and heterogeneous chemistry. The observations show a wide range from $-50 \%$ to $+90 \%$, and Graedel and Keene (1995) emphasize that uncertainties are large. Slight negative deficits in the observations could be caused by titration of alkalinity by $\mathrm{HCl}$ but large negative deficits are likely due to error. Mean model deficits sampled for the regions and months of the observations range from +4 to $+40 \%$, not inconsistent with the observations. The largest model deficits are in polluted coastal regions because of acid displacement and this is also where the measured deficits are largest.

Figure 4 compares simulated $\mathrm{HCl}$ and $\mathrm{HNO}_{3}$ mixing ratios to concurrent observations of gases both at coastal sites and over oceans. The data are arranged from left to right by increasing latitude. Mean $\mathrm{HCl}$ mixing ratios average $323 \mathrm{ppt}$ in the model and $347 \mathrm{ppt}$ in the observations for the ensemble 
Table 3. Chloride deficits in sea salt aerosol ${ }^{\mathrm{a}}$.

\begin{tabular}{llr}
\hline Location & $\begin{array}{l}\text { Modeled } \mathrm{Cl}^{-} \\
\text {deficit }(\%)\end{array}$ & $\begin{array}{r}\text { Measured } \mathrm{Cl}^{-} \\
\text {deficit }(\%)\end{array}$ \\
\hline North Carolina coast & +40 & -1 to +90 \\
Townsville coast, Australia & +23 & +33 \\
California coast & +21 & +2 to +75 \\
Greenland Sea & +18 & +6 to +22 \\
North Atlantic Ocean & +14 & -24 to +54 \\
Equatorial Atlantic & +12 & +11 to +64 \\
Puerto Rico coast & +9 & +7 to +25 \\
Pacific Ocean & +6 & $-22 \sim+40$ \\
Cape Grim, Australia & +4 & $-50 \sim+15$ \\
\hline
\end{tabular}

${ }^{a}$ Deficits relative to seawater composition. Observations compiled by Graedel and Keene (1995) are reported there as ranges for individual regions and months, with the ranges likely reflecting measurement uncertainty rather than physical variability. Model values are means for the regions and months of observations.

of regions. The $\mathrm{HCl}$ source in the model is mainly acid displacement from SSA. A sensitivity simulation without acid displacement from SSA has less than $7 \mathrm{ppt} \mathrm{HCl}$ in all regions. The model captures the spatial variability of the mean $\mathrm{HCl}$ mixing ratios across locations $(r=0.88)$, which largely reflects the $\mathrm{HCl}$ enhancement at polluted coastal sites and northern midlatitudes (Fig. 2). Simulated $\mathrm{HNO}_{3}$ mixing ratios average $190 \mathrm{ppt}$ across locations compared to $137 \mathrm{ppt}$ in the observations, again with good simulation of spatial variability $(r=0.96)$ driven by $\mathrm{NO}_{x}$ emissions. $\mathrm{HNO}_{3}$ mixing ratios are sensitive to acid displacement from SSA, as the sensitivity simulation without acid displacement shows mean values of $441 \mathrm{ppt}$ that are much higher than observed. This could partly explain the general model problem of $\mathrm{HNO}_{3}$ overestimation in remote air (Bey et al., 2001).

Figure 5 shows 2016 annual mean observations of $\mathrm{PM}_{2.5}$ $\mathrm{Cl}^{-}$(mass concentration in particles less than $2.5 \mu \mathrm{m}$ diameter) from the US Interagency Monitoring of Protected Visual Environments (IMPROVE) network (Malm et al., 1994). Corresponding model values shown as background contours for fine $\mathrm{Cl}^{-}(<1 \mu \mathrm{m}$ diameter and internally mixed with SNA aerosol) are for total $\mathrm{Cl}^{-}$. One would expect the IMPROVE concentrations to be higher than the model fine $\mathrm{Cl}^{-}$(because of the larger size cut) and lower than total $\mathrm{Cl}^{-}$, and this is generally the case. The model is consistent with observations in the continental interior, which we attribute to inland transport of marine $\mathrm{HCl}$ incorporated into SNA aerosol. Fine $\mathrm{Cl}^{-}$concentrations can actually be higher over the continent than over the ocean because of $\mathrm{HCl}$ displacement from the coarse SSA followed by recondensation on anthropogenic SNA aerosol. The model underestimates the observations over the Southwest US and this may be due to a missing dust source. We find that IMPROVE $\mathrm{Cl}^{-}$and dust concentrations are positively correlated $(R=0.3-0.9)$ in this region.

A number of surface air measurements have been made of $\mathrm{Cl}^{*}$ as the water-soluble component of $\mathrm{Cl}_{y}$ after removal of $\mathrm{HCl}$ (Keene et al., 1990), although most of these measure-

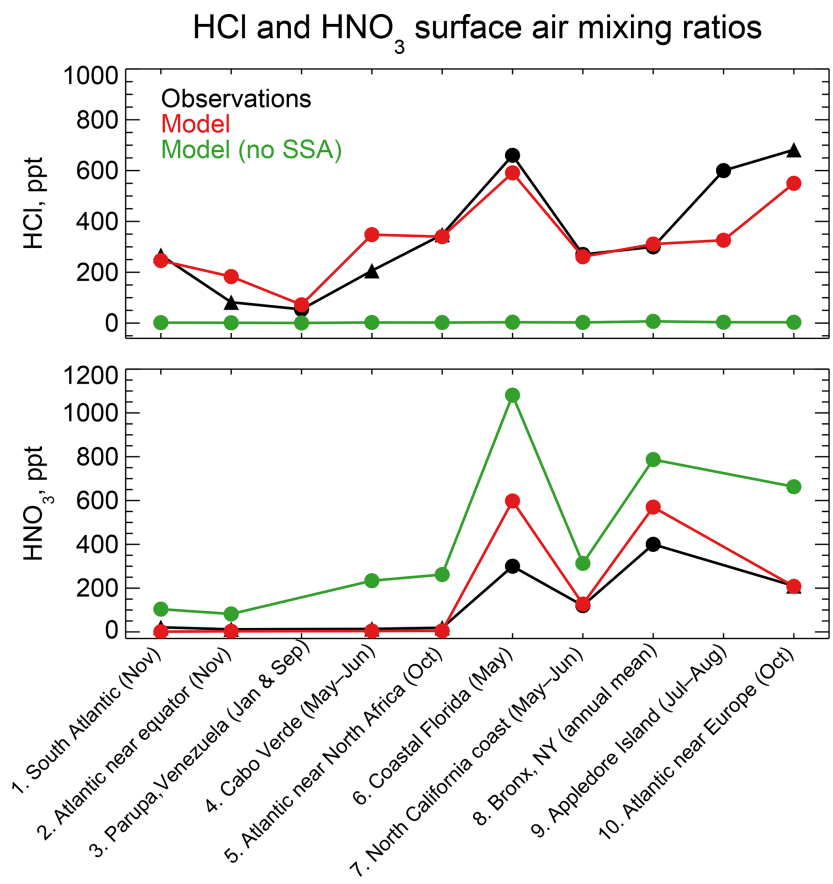

Figure 4. $\mathrm{HCl}$ and $\mathrm{HNO}_{3}$ surface air mixing ratios at coastal and island sites and from ocean cruises, arranged from left to right in order of increasing latitude. Observations are means (black circles) or medians (black triangles) depending on availability from the publications. Model values are monthly means for the sampling locations. Also shown are results from a sensitivity simulation with no mobilization of $\mathrm{Cl}^{-}$from sea salt aerosol (SSA). References: (1, 2, 5, 10) Keene et al. (2009); (3) Sanhueza and Garaboto (2002); (4) Sander et al. (2013); (6) Dasgupta et al. (2007); (7) Crisp et al. (2014); (8) Bari et al. (2003); (9) Keene et al. (2007).

ments are below the detection limit (Table 4, mostly from Keene et al., 2009). This $\mathrm{Cl}^{*}$ has been commonly assumed to represent the sum of $\mathrm{Cl}_{2}$ and $\mathrm{HOCl}$ (Pszenny et al., 1993) but it would also include $\mathrm{ClNO}_{2}, \mathrm{ClNO}_{3}$, and minor components of $\mathrm{Cl}^{*}$. Table 4 shows that simulated $\mathrm{Cl}^{*}$ mixing ratios are consistent with the measurements to the extent that comparison is possible. Simulated $\mathrm{Cl}^{*}$ over remote oceans is dominated by $\mathrm{HOCl}$, but $\mathrm{ClNO}_{2}$ is responsible for the high values over the Atlantic Ocean near Europe.

Lawler et al. (2009) measured $\mathrm{Cl}_{2}$ and $\mathrm{BrCl}$ mixing ratios at Cabo Verde in the tropical Atlantic for 5 days in MayJune 2007, and Lawler et al. (2011) measured $\mathrm{Cl}_{2}$ and $\mathrm{HOCl}$ mixing ratios at the same site for 7 days in May-June 2009. The observations show a diurnal cycle with mixing ratios of $\mathrm{Cl}_{2}$ highest at night, and $\mathrm{HOCl}$ highest in the day, consistent with the model. Observed mixing ratios in background marine air are in the range $0-30 \mathrm{ppt}$ for $\mathrm{Cl}_{2}$ and $0-2 \mathrm{ppt}$ for $\mathrm{BrCl}$ at night and $0-5 \mathrm{ppt}$ for $\mathrm{HOCl}$ in the daytime. Corresponding mean model values are $0.3 \mathrm{ppt}$ for $\mathrm{Cl}_{2}, 1.8 \mathrm{ppt}$ for $\mathrm{BrCl}$, and $5 \mathrm{ppt}$ for $\mathrm{HOCl}$, with little day-to-day variability. Lawler et al. (2011) also sampled long-range outflow from Europe for 3 days in 2009 with daytime $\mathrm{HOCl}$ and nighttime $\mathrm{Cl}_{2}$ mix- 


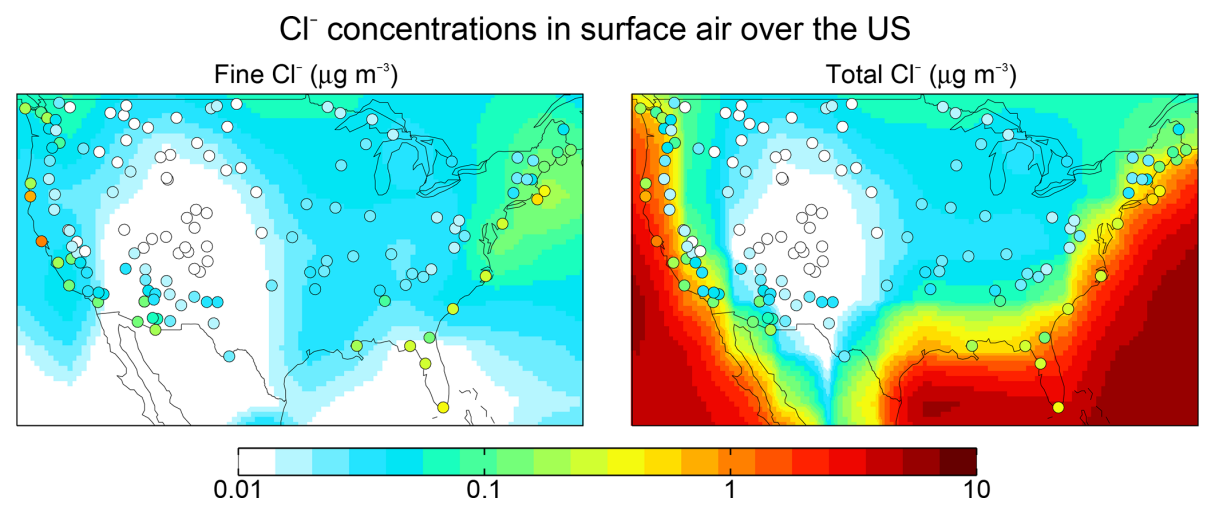

Figure 5. Aerosol $\mathrm{Cl}^{-}$concentrations in surface air over the contiguous US. Values are annual means for 2016. GEOS-Chem model values are shown as contours separately for fine $\mathrm{Cl}^{-}(<1 \mu \mathrm{m}$ diameter $)$ and total $\mathrm{Cl}^{-}$. Observations from the IMPROVE network $(<2.5 \mu \mathrm{m}$ diameter $)$ are shown as circles and are the same in both panels; one would expect them to be higher than the model fine $\mathrm{Cl}^{-}$but lower than total $\mathrm{Cl}^{-}$.

Table 4. Surface air mixing ratios of reactive chlorine $\left(\mathrm{Cl}^{*}\right)^{\mathrm{a}}$

\begin{tabular}{lrll}
\hline Location & $\begin{array}{l}\text { Modeled } \\
\mathrm{Cl}^{*}(\mathrm{ppt})\end{array}$ & $\begin{array}{l}\text { Measured mean } \\
\mathrm{Cl}^{*}(\mathrm{ppt})\end{array}$ & Reference \\
\hline Atlantic cruise near Europe & 43 & $27^{\mathrm{b}}$ & Keene et al. (2009) \\
Appledore Island (US east coast) & 17 & $<20$ & Keene et al. (2007) \\
Atlantic cruise near North Africa & 5 & $<24$ & Keene et al. (2009) \\
Southern Ocean cruise & 4 & $<24$ & Keene et al. (2009) \\
Hawaii & 4 & 6 & Pszenny et al. (2004) \\
Tropical Atlantic cruise & 2 & $<24$ & Keene et al. (2009) \\
Alert (Canada) & 0.2 & $<14$ & Impey et al. (1999) \\
\hline
\end{tabular}

${ }^{a}$ Reactive chlorine $\mathrm{Cl}^{*}$ is the ensemble of gas-phase inorganic chlorine species excluding $\mathrm{HCl}$. Measurements are $24 \mathrm{~h}$ averages. Model values are monthly means in 2016 taken for the same month and location as the observations.

${ }^{\mathrm{b}}$ Median value.

ing ratio ranges of 40-200 and 5-40 ppt, respectively, but the model does not capture these enhancements. Sommariva and von Glasow (2012) suggested that a lower aerosol pH and/or slower rate for $\mathrm{HOCl}+\mathrm{Cl}^{-}$could explain the high $\mathrm{HOCl}$ in European outflow but this would also cause $\mathrm{Cl}_{2}$ to be lower. We have no explanation for the high $\mathrm{Cl}_{2}$ values observed by Lawler et al. $(2009,2011)$ in marine air or for the joint observed enhancements of $\mathrm{HOCl}$ and $\mathrm{Cl}_{2}$ in European outflow.

Many surface observations of $\mathrm{ClNO}_{2}$ have been made in nighttime urban environments. These are difficult to compare to the model because of the $4^{\circ} \times 5^{\circ}$ grid resolution and because of nighttime stratification of the surface layer (the lowest model grid level extends up to $130 \mathrm{~m}$ above the surface). In addition, the publications usually report maxima instead of means. Table 5 shows a comparison for representative sites, indicating that the model offers a credible simulation within the above caveats. The previous GEOS-Chem simulation of Sherwen et al. (2016b) only considered $\mathrm{ClNO}_{2}$ production in $\mathrm{SSA}$ and as a result their $\mathrm{ClNO}_{2}$ mixing ratios were consistently below a few parts per trillion at continental sites. Our simulation can reproduce the observed $>100$ ppt concentrations at these sites because it accounts for $\mathrm{HCl}$ dissolved in SNA aerosol, allowing marine influence to extend further in- land as also shown in the comparison to the IMPROVE $\mathrm{Cl}^{-}$ data (Fig. 5).

\subsection{Comparison to aircraft measurements}

The WINTER aircraft campaign over the eastern US and offshore in February-March 2015 provides a unique data set for evaluating our model. Measurements included $\mathrm{HCl}, \mathrm{ClNO}_{2}$, $\mathrm{HOCl}, \mathrm{Cl}_{2}$, and $\mathrm{ClNO}_{3}$ by iodide, time of flight, chemical ionization mass spectrometry (I-TOF-CIMS) (Lee et al., 2018). We focus on the first four measurements because calibration for $\mathrm{ClNO}_{3}$ needs further examination. The mean $1 \mathrm{~s}$ detection limits for $\mathrm{HCl}, \mathrm{ClNO}_{2}, \mathrm{HOCl}$, and $\mathrm{Cl}_{2}$ were 100 , 2, 2, and 1 ppt, respectively (Lee et al., 2018). The estimated calibration uncertainty is $\pm 30 \%$ for all chlorine species. As discussed in Lee et al. (2018), labeled $15-\mathrm{N}_{2} \mathrm{O}_{5}$ was added to the inlet tip during WINTER flights to quantify inlet production of $\mathrm{ClNO}_{2}$, which was found to be negligible ( $\ll 10 \%$ of measured $\mathrm{ClNO}_{2}$ ), but inlet production of $\mathrm{Cl}_{2}$, for example from surface reactions of $\mathrm{HOCl}$ with adsorbed $\mathrm{HCl}$, was not evaluated.

Figure 6 compares the observed median vertical profiles of $\mathrm{HCl}, \mathrm{ClNO}_{2}, \mathrm{HOCl}$, and $\mathrm{Cl}_{2}$ in WINTER to the model 
Table 5. Comparison of modeled maximum $\mathrm{ClNO}_{2}$ mixing ratios to surface observations ${ }^{\mathrm{a}}$.

\begin{tabular}{|c|c|c|c|c|}
\hline Location & Date & $\begin{array}{r}\text { Observed } \\
(\mathrm{ppt})\end{array}$ & $\begin{array}{r}\text { Simulated } \\
(\mathrm{ppt})\end{array}$ & References \\
\hline Manchester, UK & October-November 2014 & 510 & 400 & Priestley et al. (2018) \\
\hline Weybourne, UK & June-August 2015 & 1100 & 1200 & Sommariva et al. (2018) \\
\hline East Anglia Coast, UK & January 2014 & 100 & 400 & Bannan et al. (2017) \\
\hline Leicester, UK & February 2016 & 730 & 760 & Sommariva et al. (2018) \\
\hline London, UK & July-August 2012 & 730 & 510 & Bannan et al. (2015) \\
\hline Calgary, Canada & April 2010 & 240 & 130 & Mielke et al. (2011) \\
\hline Calgary, Canada & September 2010-March 2011 & 340 & 170 & Mielke et al. (2015) \\
\hline Penlee Point, UK & April-May 2015 & 920 & 870 & Sommariva et al. (2018) \\
\hline Kleiner Feldberg, Germany & August-September 2011 & 850 & 400 & Phillips et al. (2012) \\
\hline Long Island Sound & March 2008 & 200 & 210 & Kercher et al. (2009) \\
\hline Olympic Park, South Korea & May-June 2016 & 780 & 520 & Jeong et al. (2018) \\
\hline Taehwa Research Forest, South Korea & May-June 2016 & 2600 & 220 & Jeong et al. (2018) \\
\hline Boulder, Colorado & February 2009 & 440 & 130 & Thornton et al. (2010) \\
\hline Pasadena, California & May-June 2010 & 3500 & 360 & Mielke et al. (2013) \\
\hline Offshore of Los Angeles, California & May-June 2010 & 1800 & 500 & Riedel et al. (2013) \\
\hline La Jolla, California & February 2013 & 65 & 65 & Kim et al. (2014) \\
\hline Houston, Texas & August-September 2006 & 1200 & 150 & Osthoff et al. (2008) \\
\hline Houston, Texas & September 2013 & 140 & 18 & Faxon et al. (2015) \\
\hline Hong Kong, China & August 2012 & 1900 & 200 & Tham et al. (2014) \\
\hline Hong Kong, China & November-December 2013 & 4700 & 410 & Wang et al. (2016) \\
\hline
\end{tabular}

a Observed and modeled values are maxima for the reporting period. Model maxima are based on hourly values sampled at the same location and time period as the observations. The sites are listed in order of decreasing latitude.

sampled along the flight tracks for the corresponding period. Figure 7 compares the median diurnal variations below $1 \mathrm{~km}$ in altitude, separately over ocean and land. We exclude daytime (10:00-16:00 local) data for $\mathrm{ClNO}_{2}$ in Fig. 6 because its mixing ratios are near zero (Fig. 7).

The WINTER observations of $\mathrm{HCl}$ show median values of $380 \mathrm{ppt}$ near the surface, dropping to a background of 100 $200 \mathrm{ppt}$ in the free troposphere (Fig. 6). The model is lower than the observations in the lowest $2 \mathrm{~km}$ but within the calibration uncertainty. The free tropospheric background in the model is much lower than observed but the observations are near the $100 \mathrm{ppt}$ detection limit. $\mathrm{HCl}$ mixing ratios in the lowest kilometer average $60 \%$ higher over ocean than over land in both the observations and the model, reflecting the marine source.

Also shown in Fig. 6 is a sensitivity simulation including anthropogenic $\mathrm{HCl}$ emissions from McCulloch et al. (1999) as described in Sect. 2.2. The resulting model mixing ratios are too high though still within the calibration uncertainty. Based on sampling of power plant plumes during the WINTER campaign, Lee et al. (2018) inferred a $\mathrm{HCl}: \mathrm{SO}_{2}$ emission mass ratio of 0.033 from power plants. Adding this emission to the standard simulation scaled to the $\mathrm{SO}_{2}$ emissions in GEOS-Chem (from the EPA National Emission Inventory over the US) increases modeled mixing ratios of $\mathrm{HCl}$ in the continental boundary layer by $18 \%$ along the WINTER flight tracks, improving agreement with observations relative to the standard simulation but still representing a rel- atively minor source. $\mathrm{ClNO}_{2}, \mathrm{HOCl}$, and $\mathrm{Cl}_{2}$ mixing ratios increase by $12 \%, 8 \%$, and $4 \%$, respectively.

Figure 8 compares the model $\mathrm{HCl}$ vertical profiles to measurements by the Georgia Tech CIMS instrument during the SEAC ${ }^{4} \mathrm{RS}$ campaign over the Southeast US in August-September 2013 (Toon et al., 2016), the KORUS-AQ campaign over and around the Korean peninsula in MayJune 2015, and the INTEX-B campaign over the North Pacific in May 2006 (Kim et al., 2008). The standard model simulation without anthropogenic chlorine successfully simulates the boundary layer $\mathrm{HCl}$ observations during $\mathrm{SEAC}^{4} \mathrm{RS}$ and KORUS-AQ but adding the McCulloch et al. (1999) anthropogenic inventory results in large overestimates. Boundary layer $\mathrm{HCl}$ mixing ratios over land are much lower in SEAC ${ }^{4} \mathrm{RS}$ than in WINTER and this is well reproduced by the model, for which the difference is due to seasonal contrast in the SSA source and in the inflow of marine air. The free tropospheric background observed in SEAC ${ }^{4} \mathrm{RS}$, KORUS$\mathrm{AQ}$, and INTEX-B data is only $\sim 25 \mathrm{ppt}$, much lower than in WINTER (100-200 ppt), whereas the model free tropospheric background is consistently $20-50 \mathrm{ppt}$ in all four campaigns. The WINTER observations are near their $100 \mathrm{ppt}$ detection limit as pointed out above. The modeled vertical profile of $\mathrm{HCl}$ during INTEX-B is very similar to that of KORUS-AQ but overestimates observed boundary layer $\mathrm{HCl}$ by a factor of 5 . The median value of observed surface $\mathrm{HCl}$ mixing ratio is 24 ppt during INTEX-B, which is much lower than all the surface air observations in Sect. 4.1. 


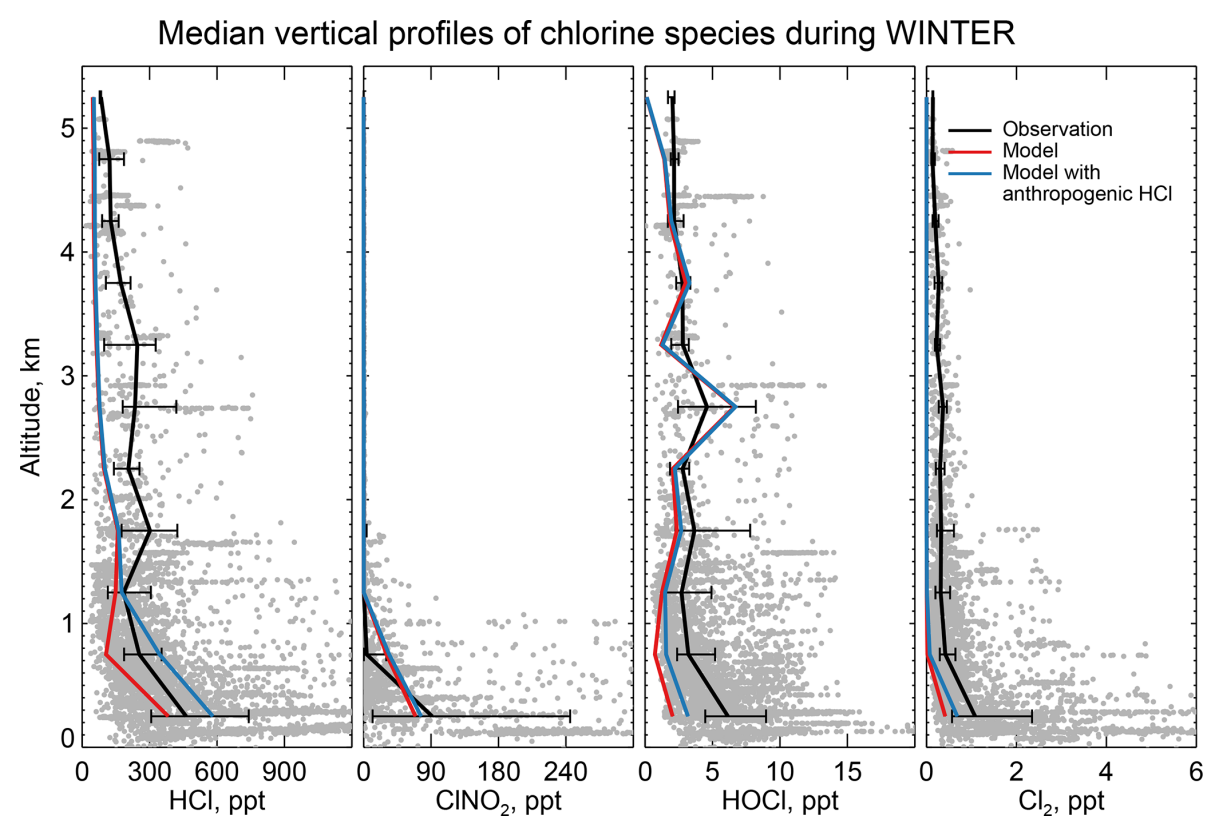

Figure 6. Vertical profiles of $\mathrm{HCl}$, nighttime $\mathrm{ClNO}_{2}, \mathrm{HOCl}$, and $\mathrm{Cl}_{2}$ mixing ratios during the WINTER campaign over the eastern US and offshore in February-March 2015. Observations from Haskins et al. (2018) are shown as individual 1 min data points, with medians and 25th-75th percentiles in $500 \mathrm{~m}$ vertical bins. Measurements below the detection limit are treated as the median of 0 and detection limit. $\mathrm{ClNO}_{2}$ data exclude daytime (10:00-16:00 local) when mixing ratios are near zero in both the observations and the model (Fig. 7). Model values are shown as medians sampled along the flight tracks. Also shown are results from a sensitivity simulation including the anthropogenic chlorine inventory of McCulloch et al. (1999).

Mixing ratios of $\mathrm{ClNO}_{2}$ observed in WINTER are above the detection limit only in the lowest kilometer of atmosphere at night and are much higher over the ocean than over land. This is well simulated by the model (Figs. 6 and 7) and reflects the nighttime source from the $\mathrm{N}_{2} \mathrm{O}_{5}+\mathrm{Cl}^{-}$heterogeneous reaction combined with the fast loss by photolysis in daytime. Previous studies have suggested that the Bertram and Thornton (2009) representation of the $\mathrm{ClNO}_{2}$ production yield from the $\mathrm{N}_{2} \mathrm{O}_{5}+\mathrm{Cl}^{-}$heterogeneous reaction in Table 2 is too high (Riedel et al., 2013; Wagner et al., 2013; McDuffie et al., 2018a). By using a box model applied to the WINTER observations, McDuffie et al. (2018a, b) found that both the $\mathrm{N}_{2} \mathrm{O}_{5}$ uptake rate and the $\mathrm{ClNO}_{2}$ production yield were overestimated by the Bertram and Thornton (2009) parameterization. One important difference with these previous studies is the assumption of aerosol mixing state. GEOS-Chem assumes that $\mathrm{Cl}^{-}$is present only in SNA and SSA when doing the calculation of $\mathrm{N}_{2} \mathrm{O}_{5}$ reactive uptake rates, assuming an external mixture of aerosol types (Martin et al., 2003; Evans and Jacob, 2005; Jaeglé et al., 2018). This decreases both the $\mathrm{N}_{2} \mathrm{O}_{5}$ uptake rate and the $\mathrm{ClNO}_{2}$ yield compared to using the parameterization of Bertram and Thornton (2009) on internally mixed aerosols. Jaeglé et al. (2018) reported that using this external mixing assumption leads to good agreement between modeled and observed $\mathrm{N}_{2} \mathrm{O}_{5}$ during the WINTER campaign. The mean $\mathrm{ClNO}_{2}$ yield ( $\varphi$ in Reaction R3) below $1 \mathrm{~km}$ in our model is 0.20 during the WINTER cam- paign, very close to that calculated from observation (0.218) by McDuffie et al. (2018a).

Nighttime $\mathrm{Cl}_{2}$ mixing ratios in WINTER are greatly overestimated by the model. Under polluted wintertime conditions such as in WINTER the $\mathrm{ClNO}_{2}+\mathrm{Cl}^{-}$reaction greatly enhances $\mathrm{Cl}_{2}$ production in the model:

$$
\mathrm{ClNO}_{2}+\mathrm{Cl}^{-} \rightarrow \mathrm{NO}_{2}^{-}+\mathrm{Cl}_{2}
$$

The reactive uptake coefficient for Reaction (R7) in Table 2 is based on a single laboratory study (Roberts et al., 2008). It requires an aerosol $\mathrm{pH}<2$ and this condition is generally met for our model simulation of the WINTER environment, consistent with the observation-based analysis of aerosol $\mathrm{pH}$ by Guo et al. (2016) for the eastern US in winter. A sensitivity simulation without Reaction (R7) is shown as dashed red lines in Fig. 7 and can reproduce the low $\mathrm{Cl}_{2}$ mixing ratios observed over the ocean at night. The analysis of WINTER data by McDuffie et al. (2018b) finds that the correlation between particle acidity and $\mathrm{Cl}_{2}$ observations is opposite of the trend expected from Reaction (R7), though there may be no trend on sufficiently acidic (i.e., $\mathrm{pH}<2$ ) aerosol. Further study of that reaction is needed. Similar reactions such as $\mathrm{ClNO}_{2}+\mathrm{Br}^{-}$(Reaction $\mathrm{R} 8$ ) and $\mathrm{ClNO}_{2}+\mathrm{I}^{-}$are also very uncertain as their reaction rate coefficients are very different in different studies (Fickert et al., 1998; Frenzel et al., 1998; Schweitzer et al., 1998). 
Diurnal variations in chlorine species during WINTER

(a) Ocean
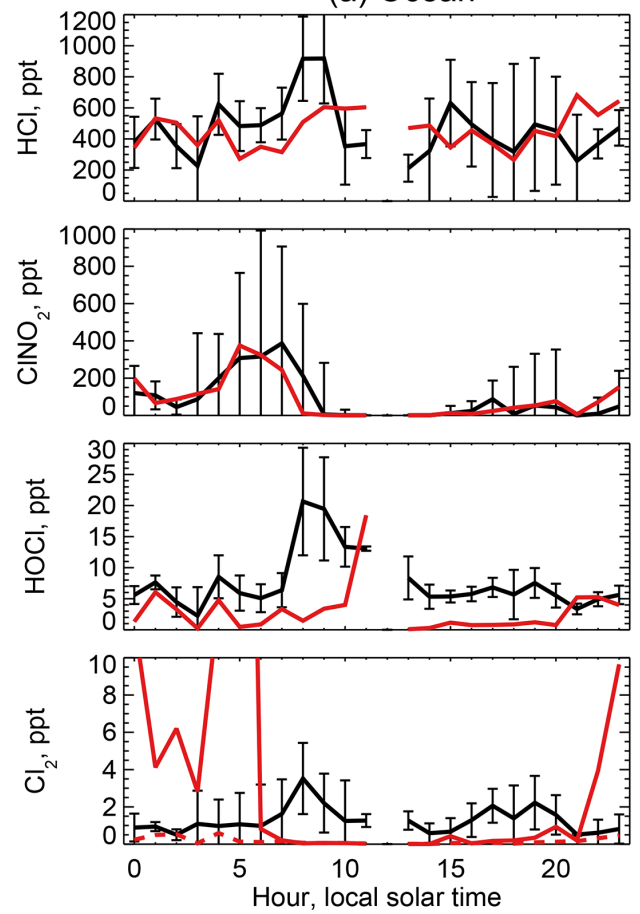

(b) Land
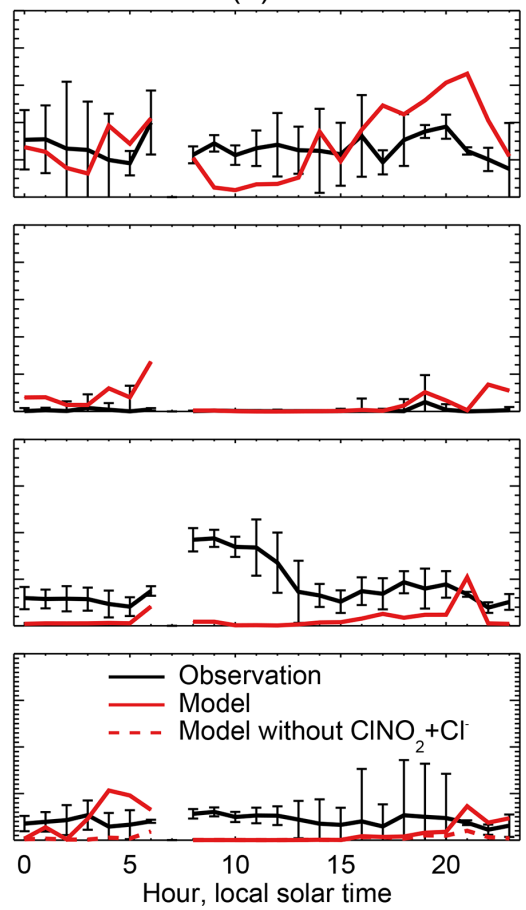

Figure 7. Median diurnal variations in $\mathrm{HCl}, \mathrm{ClNO}_{2}$, and $\mathrm{Cl}_{2}$ mixing ratios below $1 \mathrm{~km}$ in altitude during the WINTER aircraft campaign over the eastern US and offshore in February-March 2015. The data are separated between ocean (a) and land (b). Model values are compared to observations from Haskins et al. (2018). Vertical bars show the 25th-75th percentiles in the observations. Measurements below the detection limit are treated as the median of 0 and detection limit. Also shown are results from a sensitivity simulation excluding $\mathrm{ClNO}_{2}+\mathrm{Cl}^{-}$, which has a negligible effect on $\mathrm{HCl}, \mathrm{ClNO}_{2}$, and $\mathrm{HOCl}$ but brings the $\mathrm{Cl}_{2}$ simulation in much better agreement with observations at night.

The model underestimates the WINTER observations of $\mathrm{HOCl}$ and $\mathrm{Cl}_{2}$ in daytime, over the ocean as well as over land. These species have short lifetimes due to photolysis (less than a few minutes). Direct anthropogenic emission from coal combustion has been proposed (Chang et al., 2002) but would only be observed in plumes and not over the oceans. Matching the $>1 \mathrm{ppt} \mathrm{Cl}_{2}$ observed during daytime is particularly problematic since it would require a large photochemical source absent from the model. Lawler et al. (2011) suggested a fast daytime $\mathrm{HOCl}$ source from a hypothetical lightdependent $\mathrm{Cl}^{-}$oxidation. The measurements of $\mathrm{Cl}_{2}$ are also possibly subject to a positive artifact from rapid heterogeneous conversion of chlorine species on the surface of the TOF-CIMS inlet (Lee et al., 2018).

\section{Global implications of tropospheric chlorine chemistry}

\subsection{Cl atom and its impact on VOCs}

The global mean pressure-weighted tropospheric $\mathrm{Cl}$ atom concentration in our simulation is $620 \mathrm{~cm}^{-3}$, while the MBL concentration averages $1200 \mathrm{~cm}^{-3}$ (Fig. 2). Our global mean is lower than the previous global model studies of Hossaini et al. (2016) $\left(1300 \mathrm{~cm}^{-3}\right)$ and Long et al. (2014) $\left(3000 \mathrm{~cm}^{-3}\right)$, which had excessive $\mathrm{Cl}^{*}$ generation as discussed above. It is consistent with the upper limit of $1000 \mathrm{~cm}^{-3}$ inferred by Singh et al. (1996) from global modeling of $\mathrm{C}_{2} \mathrm{Cl}_{4}$ observations $\left(\mathrm{C}_{2} \mathrm{Cl}_{4}\right.$ is highly reactive with $\mathrm{Cl}$ atoms). Isotopic observations of methane have been used to infer a $\mathrm{Cl}$ atom concentration in the MBL higher than $9000 \mathrm{~cm}^{-3}$ in the extratropical Southern Hemisphere (Platt et al., 2004; Allan et al., 2007), much higher than our estimate of $800 \mathrm{~cm}^{-3}$ over this region. More recently, Gromov et al. (2018) revisited these data together with added constraints from $\mathrm{CO}$ isotope measurements and concluded that extratropical Southern Hemisphere concentrations of $\mathrm{Cl}$ atoms in the MBL should be lower than $900 \mathrm{~cm}^{-3}$, consistent with our estimate.

Tropospheric oxidation by $\mathrm{Cl}$ atoms drives a present-day methane loss rate of $5.3 \mathrm{Tg} \mathrm{a}^{-1}$ in our model, contributing only $1.0 \%$ of total methane chemical loss. It has a more significant impact on the oxidation of some other VOCs, contributing $20 \%$ of the global loss for ethane, $14 \%$ for propane, $10 \%$ for higher alkanes, and $4 \%$ for methanol. 
$\mathrm{HCl}$ vertical profiles
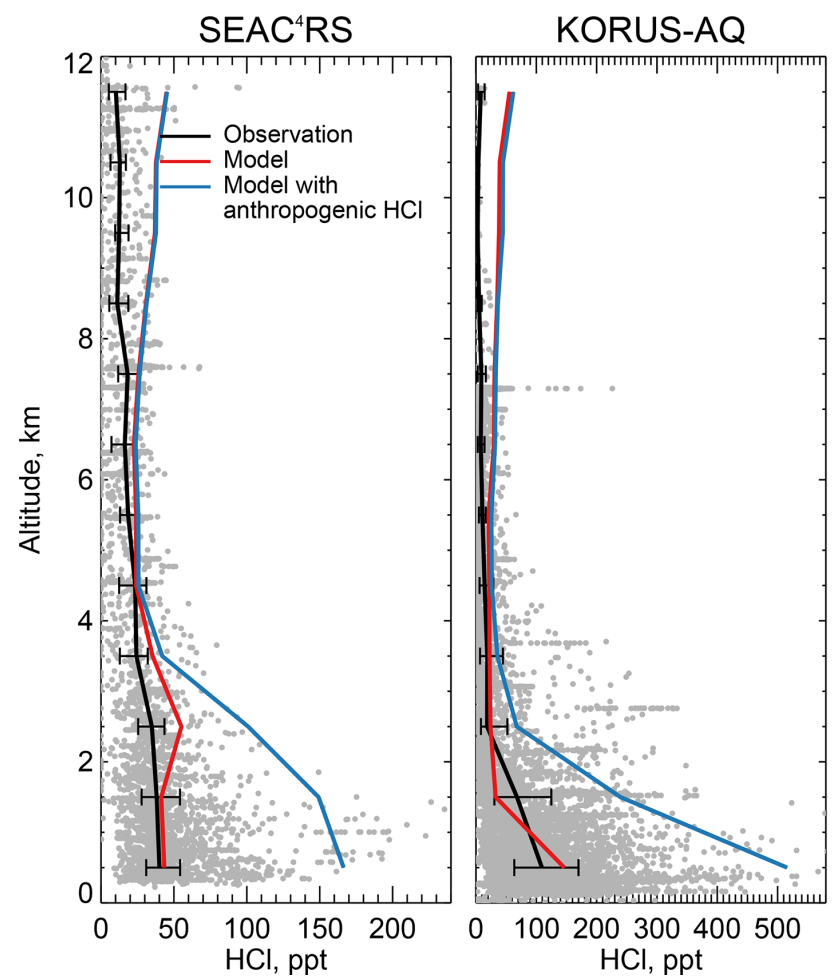

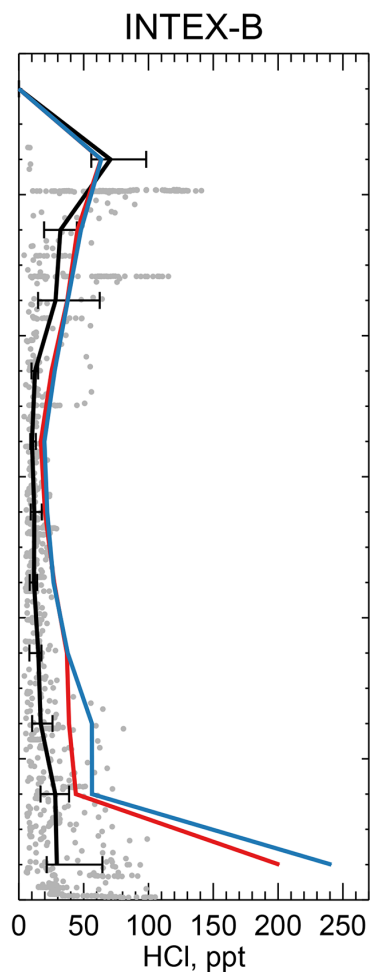

Figure 8. Vertical profiles of $\mathrm{HCl}$ mixing ratios during the SEAC ${ }^{4} \mathrm{RS}$ aircraft campaign over the Southeast US $\left(95-81.5^{\circ} \mathrm{W}, 30.5-39^{\circ} \mathrm{N}\right)$ in August-September 2013, during the KORUS-AQ aircraft campaign over and around the Korean peninsula $\left(120-132^{\circ} \mathrm{E}, 32-38^{\circ} \mathrm{N}\right)$ in May-June 2015 and during the INTEX-B aircraft campaign over the North Pacific $\left(175^{\circ} \mathrm{E}-50^{\circ} \mathrm{W}, 40-61^{\circ} \mathrm{N}\right)$ in May 2006 . Observations from the Georgia Tech CIMS instrument are shown as gray points (1 min averages), with medians and 25th-75th percentiles in $1 \mathrm{~km}$ vertical bins. Model values are sampled along the flight tracks and for the measurement period. Measurements below the detection limit are treated as the median of 0 and detection limit. Note the difference in scales among panels.

\subsection{Impact on bromine and iodine chemistry}

Bromine radicals $\left(\mathrm{BrO}_{x} \equiv \mathrm{Br}+\mathrm{BrO}\right)$ and iodine radicals $\left(\mathrm{IO}_{x} \equiv \mathrm{I}+\mathrm{IO}\right)$ affect global tropospheric chemistry by depleting ozone and OH (Parrella et al., 2012; Sherwen et al., 2016b). Br atoms are also thought to drive the oxidation of elemental mercury (Holmes et al., 2006). Chlorine chemistry increases $\mathrm{IO}_{x}$ mixing ratios by $16 \%$ due to the reactions of $\mathrm{HOI}, \mathrm{INO}_{2}$, and $\mathrm{INO}_{3}$ with $\mathrm{Cl}^{-}$(Reactions R11-R13), producing ICl, which photolyzes rapidly to I atoms (Fig. 1). The effect on bromine is more complicated. Bromine radicals originate from photolysis and oxidation of organobromines emitted by the ocean, as well as from SSA de-bromination (Yang et al., 2005). They are lost by conversion to $\mathrm{HBr}$, which is efficiently deposited. Parrella et al. (2012) pointed out that heterogeneous chemistry of $\mathrm{HBr}$ (dissolved as $\mathrm{Br}^{-}$) is critical for recycling bromine radicals and explaining observed tropospheric $\mathrm{BrO}$ mixing ratios in the background troposphere:

$$
\begin{aligned}
& \mathrm{HOBr}(\mathrm{aq})+\mathrm{Br}^{-}+\mathrm{H}^{+} \rightarrow \mathrm{Br}_{2}+\mathrm{H}_{2} \mathrm{O}, \\
& \mathrm{Br}_{2}+h v \rightarrow 2 \mathrm{Br} .
\end{aligned}
$$

Chloride ions and dissolved $\mathrm{SO}_{2}$ can however compete with $\mathrm{Br}^{-}$for the available $\mathrm{HOBr}$ (Chen et al., 2017):

$$
\begin{aligned}
& \mathrm{HOBr}(\mathrm{aq})+\mathrm{Cl}^{-}+\mathrm{H}^{+} \rightarrow \mathrm{BrCl}+\mathrm{H}_{2} \mathrm{O}, \\
& \mathrm{HOBr}(\mathrm{aq})+\mathrm{HSO}_{3}^{-} / \mathrm{SO}_{3}^{2-} \rightarrow \mathrm{HBr}+\mathrm{HSO}_{4}^{-} / \mathrm{SO}_{4}^{2-} .
\end{aligned}
$$

Chen et al. (2017) pointed out that Reaction (R16) effectively decreases $\mathrm{BrO}$ mixing ratios by producing $\mathrm{HBr}$, which is rapidly deposited instead of contributing to $\mathrm{BrO}_{x}$ cycling. They found in a GEOS-Chem simulation that global tropospheric $\mathrm{BrO}$ mixing ratios decreased by a factor of 2 as a result. Reaction (R5) may however have a compensating or opposite effect. It propagates the cycling of $\mathrm{BrO}_{x}$ if $\mathrm{BrCl}$ volatilizes:

$\mathrm{BrCl}+h v \rightarrow \mathrm{Br}+\mathrm{Cl}$, 
but it may also generate new $\mathrm{BrO}_{x}$ if $\mathrm{BrCl}$ reacts with $\mathrm{Br}^{-}$in the aqueous phase to produce $\mathrm{Br}_{2}$ (Wang et al., 1994):

$\mathrm{BrCl}(\mathrm{aq})+\mathrm{Br}^{-} \rightleftarrows \mathrm{Br}_{2} \mathrm{Cl}^{-}$,

$\mathrm{Br}_{2} \mathrm{Cl}^{-} \rightleftarrows \mathrm{Br}_{2}(\mathrm{aq})+\mathrm{Cl}^{-}$.

The sequence Reactions (R5) $+(\mathrm{R} 18)+(\mathrm{R} 19)$ with $\mathrm{Cl}^{-}$as a catalyst has the same stoichiometry as Reaction (R14) and thus contributes to $\mathrm{HBr}$ recycling in the same way. We find in the model that it is globally 30 times faster than Reaction (R14) and therefore much more effective at regenerating bromine radicals. In GEOS-Chem, the rate of Reaction (R5) computed from Table 2 is applied to the following stoichiometry reflecting the ensemble of Reactions (R5), (R14), (R18), and (R19):

$$
\begin{array}{cr}
\mathrm{HOBr}(\mathrm{aq})+Y \mathrm{Br}^{-}+(1-Y) \mathrm{Cl}^{-}+\mathrm{H}^{+} & \rightarrow Y \mathrm{Br}_{2} \\
+(1-Y) \mathrm{BrCl}+\mathrm{H}_{2} \mathrm{O}, & (\mathrm{R} 5, \mathrm{R} 1
\end{array}
$$

where $Y$ is the yield of $\mathrm{Br}_{2}$ and $1-Y$ is the yield of $\mathrm{BrCl}$. $Y$ is calculated following the laboratory study of Fickert et al. (1999).

$$
\begin{aligned}
& Y=0.41 \log _{10}\left(\left[\mathrm{Br}^{-}\right] /\left[\mathrm{Cl}^{-}\right]\right)+2.25 \\
& \text { for }\left[\mathrm{Br}^{-}\right] /\left[\mathrm{Cl}^{-}\right]<5 \times 10^{-4} \\
& Y=0.90 \text { for }\left[\mathrm{Br}^{-}\right] /\left[\mathrm{Cl}^{-}\right]>5 \times 10^{-4}
\end{aligned}
$$

This mechanism was first included in GEOS-Chem version 11-02d by Chen et al. (2017), who did not however have an explicit $\mathrm{SSACl}^{-}$simulation (they instead assumed a fixed $\mathrm{SSA}\left[\mathrm{Cl}^{-}\right]=0.5 \mathrm{M}$, and considered only dissolved $\mathrm{HCl}$ in cloud).

Chen et al. (2017) found in their GEOS-Chem simulation that the global tropospheric $\mathrm{BrO}$ burden was $8.7 \mathrm{Gg}$ without the $\mathrm{HOBr}+\mathrm{S}(\mathrm{IV})$ Reaction (R16) and dropped to $3.6 \mathrm{Gg}$ when that reaction was included. Previous GEOSChem model estimates of the global tropospheric BrO burden were $3.8 \mathrm{Gg}$ (Parrella et al., 2012), $5.7 \mathrm{Gg}$ (Schmidt et al., 2016), and $6.4 \mathrm{Gg}$ (Sherwen et al., 2016b). Our simulation features many updates relative to Chen et al. (2017), including not only explicit SSA Cl${ }^{-}$but also explicit calculation of aerosol $\mathrm{pH}$ with ISORROPIA II for the rates of reactions in Table 2. By including explicit $\mathrm{SSA} \mathrm{Cl}^{-}$, the cloud water $\left[\mathrm{Cl}^{-}\right]$in our model is much higher than that in Chen et al. (2017) and more comparable to measurements $\left(\sim 10^{-4} \mathrm{M}\right.$ in typical cloud; Straub et al., 2007). We find in our standard simulation a global tropospheric $\mathrm{BrO}$ burden of $4.2 \mathrm{Gg}, 17 \%$ higher than that of Chen et al. (2017).

Figure 9 shows the change in surface $\mathrm{BrO}$ mixing ratios due specifically to tropospheric chlorine chemistry, as obtained by difference with a sensitivity simulation including none of the $\mathrm{Cl}_{y}$ chemistry shown in Fig. 1. The inclusion of chlorine chemistry increases the global tropospheric $\mathrm{BrO}$ burden by $85 \%$. More than $80 \%$ of this change is caused by the $\mathrm{HOBr}+\mathrm{Cl}^{-}$reaction as discussed above. Other significant contributions include $\mathrm{ClNO}_{3}+\mathrm{Br}^{-}$and $\mathrm{ClNO}_{2}+\mathrm{Br}^{-}$. The largest $\mathrm{BrO}$ increases (1-2 ppt) are in surface air over the high-northern-latitude oceans where SSA emissions are high and acidic conditions promote $\mathrm{HOBr}+\mathrm{Cl}^{-}$chemistry.

\subsection{Impact on tropospheric ozone and $\mathrm{OH}$}

Figure 9 also shows the effects of chlorine chemistry on $\mathrm{NO}_{x}, \mathrm{OH}$, and ozone concentrations. The global tropospheric burdens decrease by $5 \%$ for $\mathrm{NO}_{x}, 3 \%$ for $\mathrm{OH}$, and $7 \%$ for ozone. The interhemispheric $(\mathrm{N} / \mathrm{S})$ ratio of tropospheric mean $\mathrm{OH}$ decreases from 1.14 to 1.12 . Models tend to overestimate global mean tropospheric $\mathrm{OH}$ and its interhemispheric ratio relative to the constraint from methyl chloroform, which suggests a ratio of 0.85-0.98 (Naik et al., 2013; Voulgarakis et al., 2013). The effect of chlorine chemistry on the $N / S$ ratio is slight but in the right direction.

The chlorine-induced decreases in Fig. 9 are mainly through bromine chemistry initiated by chlorine (Sect. 5.2) and have spatial distributions characteristic of bromine chemistry with maxima at high latitudes as discussed by Schmidt et al. (2016). There are specific chlorine mechanisms including catalytic ozone loss through $\mathrm{HOCl}$ formation and photolysis:

$\mathrm{Cl}+\mathrm{O}_{3} \rightarrow \mathrm{ClO}+\mathrm{O}_{2}$,

$\mathrm{ClO}+\mathrm{HO}_{2} \rightarrow \mathrm{HOCl}+\mathrm{O}_{2}$,

$\mathrm{HOCl} \stackrel{\mathrm{h} v}{\longrightarrow} \mathrm{Cl}+\mathrm{OH}$,

Net: $\mathrm{O}_{3}+\mathrm{HO}_{2} \rightarrow \mathrm{OH}+2 \mathrm{O}_{2}$

and also loss of $\mathrm{NO}_{x}$ :

$\mathrm{ClO}+\mathrm{NO}_{2}+\mathrm{M} \rightarrow \mathrm{ClNO}_{3}+\mathrm{M}$,

$\mathrm{ClNO}_{3}+\mathrm{H}_{2} \mathrm{O} \rightarrow \mathrm{HOCl}+\mathrm{HNO}_{3}$.

However, we find that the rates are very small compared to similar mechanisms involving bromine and iodine because the stability of $\mathrm{HCl}$ quenches $\mathrm{Cl}^{*}$ radical cycling.

A particular situation arises over polluted continents due to $\mathrm{ClNO}_{2}$ chemistry. Production of $\mathrm{ClNO}_{2}$ at night from the $\mathrm{N}_{2} \mathrm{O}_{5}+\mathrm{Cl}^{-}$heterogeneous reaction, followed by photolysis in the morning to release $\mathrm{Cl}$ and $\mathrm{NO}_{2}$, provides a source of radicals and ozone. This explains the increases in $\mathrm{OH}$ over North America and Europe in Fig. 9. The effect is most important at high northern latitudes in winter due to the longer night. To isolate the impact on ozone we conducted a sensitivity simulation with no $\mathrm{ClNO}_{2}$ production, setting $\varphi=0$ for Reaction (R3) in Table 2. The surface air ozone enhancement due to $\mathrm{ClNO}_{2}$ chemistry is found to be the largest $(\sim 8 \mathrm{ppb})$ in European winter, due to the large supply of $\mathrm{Cl}^{-}$from the North Atlantic combined with high $\mathrm{NO}_{x}$ emissions. Other polluted continents see ozone increases of $1-5 \mathrm{ppb}$ in winter. The effect in summer is less than $1 \mathrm{ppb}$. These results are 


\section{Chlorine-driven changes in $\mathrm{BrO}, \mathrm{NO}_{x}, \mathrm{OH}$, and ozone}

(a)

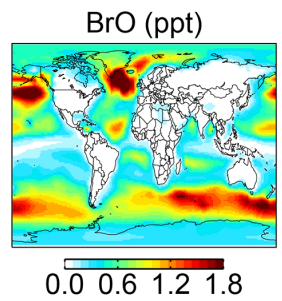

(b)
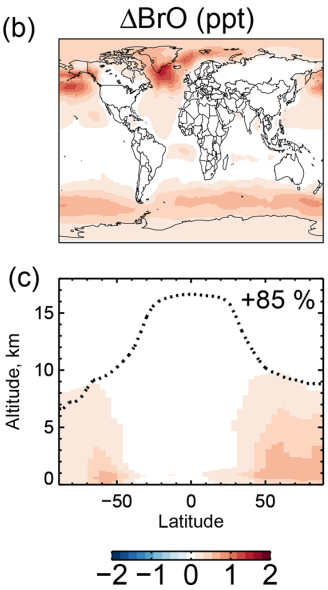
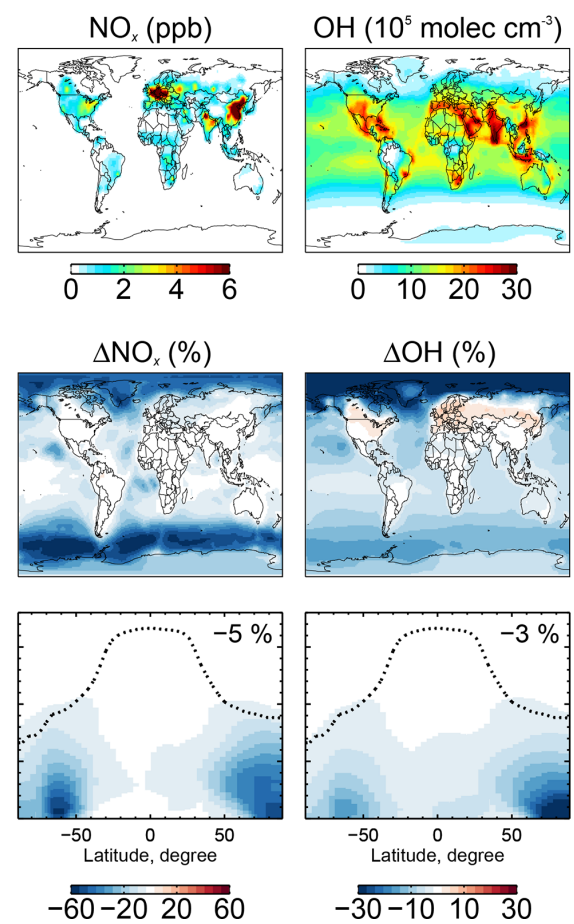

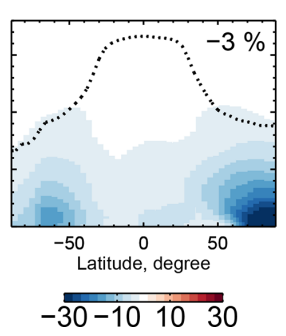

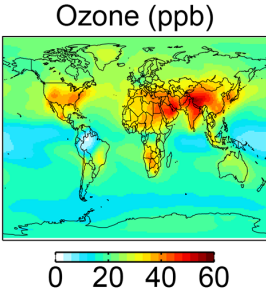

$\Delta$ Ozone $(\mathrm{ppb})$
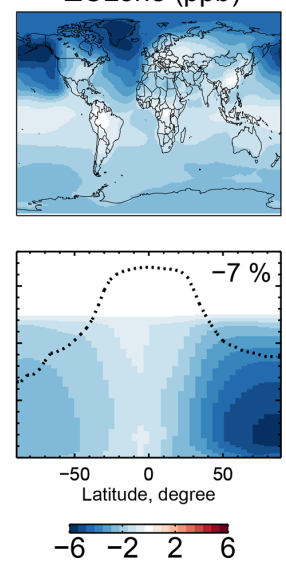

Figure 9. Effects of tropospheric chlorine chemistry on $\mathrm{BrO}, \mathrm{NO}_{x}, \mathrm{OH}$, and ozone concentrations. Panel (a) shows the annual mean surface concentrations of $\mathrm{BrO}, \mathrm{NO}_{x}, \mathrm{OH}$, and ozone simulated in our standard model including tropospheric chlorine chemistry. Panels (b) and (c) show the changes in annual mean mixing ratios and concentrations due to tropospheric chlorine chemistry, as determined by the difference with a sensitivity simulation including no $\mathrm{Cl}_{y}$ production and cycling. Panel (b) shows the changes in surface air concentrations and panel (c) shows the changes in zonal mean mixing concentrations as a function of latitude and altitude. Black dashed lines indicate the tropopause. Numbers in (c) show the global tropospheric mean differences.

similar to previous regional modeling studies by Sarwar et al. (2014) and Sherwen et al. (2017).

Figure $\mathrm{S} 1$ shows the differences of $\mathrm{BrO}, \mathrm{NO}_{x}, \mathrm{OH}$, and ozone concentrations between our model and the standard GEOS-Chem model version 11-02d including SSA debromination. Our explicit treatment of chlorine chemistry and thermodynamic representation of aerosol $\mathrm{pH}$ increases the global tropospheric $\mathrm{BrO}$ burden by $40 \%$. Most of this change is caused by faster $\mathrm{HOBr}+\mathrm{Cl}^{-}$reaction at high latitudes, resulting from higher $\mathrm{Cl}^{-}$concentration in our model, particularly in cloud. The decrease in $\mathrm{BrO}$ in the tropical MBL is caused by an increase in aerosol $\mathrm{pH}$ ( $\mathrm{pH}$ was previously assumed to be 0 for computation of bromine chemistry), which slows down the acid-catalyzed recycling of bromine by Reactions (R5) and (R14). Our computed global tropospheric burdens decrease by $4 \%$ for $\mathrm{NO}_{x}, 2 \%$ for $\mathrm{OH}$, and $4 \%$ for ozone relative to version 11-02d, again due to the more active bromine chemistry. The increase in $\mathrm{OH}$ over continental regions is due to our accounting of $\mathrm{HCl}$ dissolved in SNA aerosol, allowing marine influence to extend further inland to drive $\mathrm{ClNO}_{2}$ chemistry.

\section{Conclusions}

We have added to the GEOS-Chem model a comprehensive and consistent representation of tropospheric chlorine chemistry. This includes, in particular, explicit accounting of the mobilization of sea salt aerosol (SSA) chloride $\left(\mathrm{Cl}^{-}\right)$, by acid displacement of $\mathrm{HCl}$ as well as by other heterogeneous processes. Cycling of inorganic gas-phase chlorine species $\left(\mathrm{Cl}_{y}\right)$ generated from SSA and other sources is simulated and coupled to the model aerosol-oxidant-bromine-iodine chemistry. With our work, GEOS-Chem now has a complete simulation of halogen $(\mathrm{Cl}+\mathrm{Br}+\mathrm{I})$ chemistry in both the troposphere and stratosphere.

Emission of chlorine in the model is mainly as sea salt aerosol $\left(1780 \mathrm{Tg} \mathrm{Cla}^{-1}\right)$. Other sources (combustion, organochlorines, stratospheric input) are also included but are small in comparison. Most of the sea salt aerosol chloride is removed by deposition, but $3.6 \%$ is mobilized to inorganic gas-phase chlorine $\left(\mathrm{Cl}_{y}\right)$ through acid displacement to $\mathrm{HCl}\left(52 \mathrm{Tg} \mathrm{a}^{-1}\right)$ and through other heterogeneous chemistry producing more reactive chlorine species $\left(12 \mathrm{Tg} \mathrm{a}^{-1}\right)$. We define reactive chlorine $\left(\mathrm{Cl}^{*}\right)$ as the ensemble of $\mathrm{Cl}_{y}$ species excluding $\mathrm{HCl}$ and including $\mathrm{Cl}, \mathrm{ClO}, \mathrm{Cl}_{2}, \mathrm{BrCl}, \mathrm{HOCl}$, 
$\mathrm{ClNO}_{2}$, and $\mathrm{ClNO}_{3}$ plus other minor species. Oxidation of $\mathrm{HCl}$ by $\mathrm{OH}$ provides a $\mathrm{Cl}^{*}$ source of $9.7 \mathrm{Tg} \mathrm{a}^{-1}$, comparable to the heterogeneous source from $\mathrm{HOBr}+\mathrm{Cl}^{-}\left(8.6 \mathrm{Tg} \mathrm{a}^{-1}\right)$. $\mathrm{N}_{2} \mathrm{O}_{5}+\mathrm{Cl}^{-}\left(1.8 \mathrm{Tg} \mathrm{a}^{-1}\right)$ is also important in polluted environments. Cycling among $\mathrm{Cl}^{*}$ species drives radical chlorine $(\mathrm{Cl} / \mathrm{ClO})$ chemistry but chain lengths are limited by fast conversion to $\mathrm{HCl}$ and subsequent deposition.

$\mathrm{HCl}$ mixing ratios in the model are highest over the oceans downwind of polluted continents due to effective acid displacement from sea salt aerosol by $\mathrm{HNO}_{3}$ and $\mathrm{H}_{2} \mathrm{SO}_{4}$. Mixing ratios are much lower over the Southern Ocean where the supply of acids is low. The dominant daytime $\mathrm{Cl}^{*}$ species is generally $\mathrm{HOCl}$ while $\mathrm{BrCl}, \mathrm{Cl}_{2}$, and $\mathrm{ClNO}_{2}$ dominate at night. $\mathrm{ClNO}_{3}$ dominates in the upper troposphere due to stratospheric input. Chlorine atom concentrations are highest over Europe in winter due to $\mathrm{ClNO}_{2}$ chemistry and are otherwise high over the northern midlatitude oceans where the supply of acidity promotes $\mathrm{Cl}$ formation through both $\mathrm{HCl}$ and acid-catalyzed heterogeneous processes.

Comparison of model results to observations in marine surface air shows that the model is usually able to reproduce the range and distributions of observed sea salt aerosol chloride deficits, $\mathrm{HCl}$ mixing ratios, and $\mathrm{Cl}^{*}$ mixing ratios. In particular, concurrent observations of $\mathrm{HCl}$ and $\mathrm{HNO}_{3}$ in coastal/marine air worldwide show high correlation with the model including high $\mathrm{HCl}$ mixing ratios at northern midlatitudes combined with depressed $\mathrm{HNO}_{3}$. Consideration of acid displacement greatly improves model agreement with $\mathrm{HNO}_{3}$ observations in marine air. The model can also successfully simulate observations of high $\mathrm{ClNO}_{2}$ at night including in continental air. The chlorine in that case originates from sea salt aerosol transported far inland following uptake of volatilized $\mathrm{HCl}$ by sulfate-nitrate-ammonium (SNA) aerosol. The model cannot reproduce the very high $\mathrm{HOCl}$ and $\mathrm{Cl}_{2}$ concentrations observed by Lawler et al. $(2009,2011)$ at Cabo Verde in the tropical Atlantic.

Comparisons of model results to aircraft campaign observations from WINTER (eastern US and offshore, February-March 2015), SEAC4RS (Southeast US, AugustSeptember 2013), and KORUS-AQ (Korean peninsula, April-June 2016) show general consistency for $\mathrm{HCl}$ vertical profiles. Continental boundary layer $\mathrm{HCl}$ mixing ratios in these campaigns can be mostly accounted for by the marine source transported inland, though power plants could make a minor contribution. WINTER observations also include $\mathrm{ClNO}_{2}, \mathrm{Cl}_{2}$, and $\mathrm{HOCl}$. The observed $\mathrm{ClNO}_{2}$ is mainly confined to the nighttime marine boundary layer and is consistent with the model. Observed $\mathrm{Cl}_{2}$ concentrations at night are much lower than the model, which has a large source under the WINTER conditions from the $\mathrm{ClNO}_{2}+\mathrm{Cl}^{-}$heterogeneous reaction. The rate coefficient for this reaction is from only one laboratory study.

The model simulates a global mean $\mathrm{Cl}$ atom concentration of $620 \mathrm{~cm}^{-3}$ in the troposphere and $1200 \mathrm{~cm}^{-3}$ in the marine boundary layer (MBL), lower than previous global model studies that had excessive generation of $\mathrm{Cl}^{*}$ but consistent with independent proxy constraints. We find that oxidation by $\mathrm{Cl}$ atoms accounts for only $1.0 \%$ of the global loss of atmospheric methane but has larger effects on the global losses of ethane (20\%), propane (14\%), and methanol (4\%). Chlorine chemistry increases global tropospheric $\mathrm{BrO}$ by $85 \%$ and decreases ozone and $\mathrm{OH}$ by $7 \%$ and $3 \%$, respectively, relative to a sensitivity simulation with no chlorine chemistry. The large effect on $\mathrm{BrO}$ is due to production of bromine radicals by the $\mathrm{HOBr}+\mathrm{Cl}^{-}$heterogeneous reaction, and the decreases in ozone and $\mathrm{OH}$ are mainly through the induced bromine chemistry. An exception is winter conditions over polluted regions, for which $\mathrm{ClNO}_{2}$ chemistry increases ozone mixing ratios by up to $8 \mathrm{ppb}$.

Data availability. The model code is available from the corresponding author upon request and will be made available to the community through the standard GEOS-Chem (http://www.geos-chem.org) in the future. Data of the WINTER campaign are available to the general public at https:// www.eol.ucar.edu/field_projects/winter. Data of NASA SEAC ${ }^{4} \mathrm{RS}$, KORUS-AQ, and INTEX-B missions are available to the general public through the NASA data archive (https://www-air larc.nasa.gov/cgi-bin/ArcView/seac4rs, https://www-air.larc.nasa. gov/cgi-bin/ArcView/korusaq, and https://www-air.larc.nasa.gov/ cgi-bin/ArcView/intexb). IMPROVE data are available through the Federal Land Manager Environmental database (http://views.cira. colostate.edu/fed). All links mentioned here were last accessed on 1 March 2019.

Supplement. The supplement related to this article is available online at: https://doi.org/10.5194/acp-19-3981-2019-supplement.

Author contributions. XW, DJJ, and HL designed the study. XW developed the chlorine model code and performed the simulations and analyses. XW, SDE, MPS, LZ, QC, BA, TS, and MJE contributed to the GEOS-Chem halogen model development. BHL, JDH, FDL, and JAT conducted and processed the measurements during the WINTER campaign. GLH conducted and processed the measurements during the SEAC ${ }^{4} \mathrm{RS}$, KORUS-AQ, and INTEX-B campaigns. XW and DJJ prepared the paper with contributions from all co-authors.

Competing interests. The authors declare that they have no conflict of interest.

Acknowledgements. This work was supported by the Atmospheric Chemistry Program of the US National Science Foundation and by the Joint Laboratory for Air Quality and Climate (JLAQC) between Harvard and the Nanjing University for Information Science and Technology (NUIST). Qianjie Chen and Becky Alexander were supported by the National Science Foundation (AGS 1343077). 
We thank Prasad S. Kasibhatla for insightful discussion. WINTER data are provided by NCAR/EOL under sponsorship of the National Science Foundation (https://www.eol.ucar.edu/field_projects/ winter, last access: 1 March 2019). SEAC ${ }^{4}$ RS, KORUS-AQ, and INTEX-B data are provided by NASA LaRC Airborne Science Data for Atmospheric Composition (https://www-air.larc.nasa.gov, last access: 1 March 2019). IMPROVE is a collaborative association of state, tribal, and federal agencies and international partners. The U.S. Environmental Protection Agency is the primary funding source, with contracting and research support from the National Park Service. The Air Quality Group at the University of California, Davis is the central analytical laboratory, with ion analysis provided by the Research Triangle Institute and carbon analysis provided by the Desert Research Institute.

Review statement. This paper was edited by Rolf Sander and reviewed by three anonymous referees.

\section{References}

Abbatt, J. P. D., Lee, A. K. Y., and Thornton, J. A.: Quantifying trace gas uptake to tropospheric aerosol: recent advances and remaining challenges, Chem. Soc. Rev., 41, 6555-6581, https://doi.org/10.1039/C2CS35052A, 2012.

Alexander, B., Park, R. J., Jacob, D. J., Li, Q. B., Yantosca, R. M., Savarino, J., Lee, C. C. W., and Thiemens, M. H.: Sulfate formation in sea-salt aerosols: Constraints from oxygen isotopes, J. Geophys. Res.-Atmos., 110, D10307, https://doi.org/10.1029/2004JD005659, 2005.

Alexander, B., Allman, D. J., Amos, H. M., Fairlie, T. D., Dachs, J., Hegg, D. A., and Sletten, R. S.: Isotopic constraints on the formation pathways of sulfate aerosol in the marine boundary layer of the subtropical northeast Atlantic Ocean, J. Geophys. Res.Atmos., 117, D06304, https://doi.org/10.1029/2011JD016773, 2012.

Allan, W., Struthers, H., and Lowe C. D.: Methane carbon isotope effects caused by atomic chlorine in the marine boundary layer: Global model results compared with Southern Hemisphere measurements, J. Geophys. Res.-Atmos., 112, D04306, https://doi.org/10.1029/2006jd007369, 2007.

Ammann, M., Cox, R. A., Crowley, J. N., Jenkin, M. E., Mellouki, A., Rossi, M. J., Troe, J., and Wallington, T. J.: Evaluated kinetic and photochemical data for atmospheric chemistry: Volume VI - heterogeneous reactions with liquid substrates, Atmos. Chem. Phys., 13, 8045-8228, https://doi.org/10.5194/acp13-8045-2013, 2013.

Amos, H. M., Jacob, D. J., Holmes, C. D., Fisher, J. A., Wang, Q., Yantosca, R. M., Corbitt, E. S., Galarneau, E., Rutter, A. P., Gustin, M. S., Steffen, A., Schauer, J. J., Graydon, J. A., Louis, V. L. St., Talbot, R. W., Edgerton, E. S., Zhang, Y., and Sunderland, E. M.: Gas-particle partitioning of atmospheric $\mathrm{Hg}$ (II) and its effect on global mercury deposition, Atmos. Chem. Phys., 12, 591-603, https://doi.org/10.5194/acp-12-591-2012, 2012.

Atkinson, R.: Gas-Phase Tropospheric Chemistry of Volatile Organic Compounds: 1. Alkanes and Alkenes, J. Phys. Chem. Ref. Data, 26, 215-290, 1997.
Bannan, T. J., Booth, A. M., Bacak, A., Muller, J. B. A., Leather, K. E., Le Breton, M., Jones, B., Young, D., Coe, H., Allan, J., Visser, S., Slowik, J. G., Furger, M., Prévôt, A. S. H., Lee, J., Dunmore, R. E., Hopkins, J. R., Hamilton, J. F., Lewis, A. C., Whalley, L. K., Sharp, T., Stone, D., Heard, D. E., Fleming, Z. L., Leigh, R., Shallcross, D. E., and Percival, C. J.: The first UK measurements of nitryl chloride using a chemical ionization mass spectrometer in central London in the summer of 2012, and an investigation of the role of $\mathrm{Cl}$ atom oxidation, J. Geophys. Res.-Atmos., 120, 5638-5657, https://doi.org/10.1002/2014JD022629, 2015.

Bannan, T. J., Bacak, A., Le Breton, M., Flynn, M., Ouyang, B., McLeod, M., Jones, R., Malkin, T. L., Whalley, L. K., Heard, D. E., Bandy, B., Khan, M. A. H., Shallcross, D. E., and Percival, C. J.: Ground and Airborne U.K. Measurements of Nitryl Chloride: An Investigation of the Role of $\mathrm{Cl}$ Atom Oxidation at Weybourne Atmospheric Observatory, J. Geophys. Res.-Atmos., 122, 11154-111165, https://doi.org/10.1002/2017JD026624, 2017.

Bari, A., Ferraro, V., Wilson, L. R., Luttinger, D., and Husain, L.: Measurements of gaseous $\mathrm{HONO}, \mathrm{HNO}_{3}, \mathrm{SO}_{2}, \mathrm{HCl}, \mathrm{NH}_{3}$, particulate sulfate and $\mathrm{PM}_{2.5}$ in New York, NY, Atmos. Environ., 37, 2825-2835, https://doi.org/10.1016/s1352-2310(03)001997, 2003.

Behnke, W., George, C., Scheer, V., and Zetzsch, C.: Production and decay of $\mathrm{ClNO}_{2}$ from the reaction of gaseous $\mathrm{N}_{2} \mathrm{O}_{5}$ with $\mathrm{NaCl}$ solution: Bulk and aerosol experiments, J. Geophys. Res.Atmos., 102, 3795-3804, https://doi.org/10.1029/96JD03057, 1997.

Bertram, T. H. and Thornton, J. A.: Toward a general parameterization of $\mathrm{N}_{2} \mathrm{O}_{5}$ reactivity on aqueous particles: the competing effects of particle liquid water, nitrate and chloride, Atmos. Chem. Phys., 9, 8351-8363, https://doi.org/10.5194/acp-9-8351-2009, 2009.

Bey, I., Jacob, D. J., Yantosca, R. M., Logan, J. A., Field, B. D., Fiore, A. M., Li, Q., Liu, H. Y., Mickley, L. J., and Schultz, M. G.: Global modeling of tropospheric chemistry with assimilated meteorology: Model description and evaluation, J. Geophys. Res.-Atmos., 106, 23073-23095, https://doi.org/10.1029/2001JD000807, 2001.

Chang, S., McDonald-Buller, E., Kimura, Y., Yarwood, G., Neece, J., Russell, M., Tanaka, P., and Allen, D.: Sensitivity of urban ozone formation to chlorine emission estimates, Atmos. Environ., 36, 4991-5003, https://doi.org/10.1016/S13522310(02)00573-3, 2002.

Chen, Q., Schmidt, J. A., Shah, V., Jaeglé, L., Sherwen, T., and Alexander, B.: Sulfate production by reactive bromine: Implications for the global sulfur and reactive bromine budgets, Geophys. Res. Lett., 44, 7069-7078, https://doi.org/10.1002/2017GL073812, 2017.

Crisp, T. A., Lerner, B. M., Williams, E. J., Quinn, P. K., Bates, T. S., and Bertram, T. H.: Observations of gas phase hydrochloric acid in the polluted marine boundary layer, J. Geophys. Res.-Atmos., 119, 6897-6915, https://doi.org/10.1002/2013JD020992, 2014.

Dasgupta, P. K., Campbell, S. W., Al-Horr, R. S., Ullah, S. M. R., Li, J., Amalfitano, C., and Poor, N. D.: Conversion of sea salt aerosol to $\mathrm{NaNO}_{3}$ and the production of $\mathrm{HCl}$ : Analysis of temporal behavior of aerosol chloride/nitrate and gaseous $\mathrm{HCl} / \mathrm{HNO}_{3}$ concentrations with AIM, Atmos. Environ., 41, 4242-4257, https://doi.org/10.1016/j.atmosenv.2006.09.054, 2007. 
Eastham, S. D., Weisenstein, D. K., and Barrett, S. R. H.: Development and evaluation of the unified troposphericstratospheric chemistry extension (UCX) for the global chemistry-transport model GEOS-Chem, Atmos. Environ., 89, 52-63, https://doi.org/10.1016/j.atmosenv.2014.02.001, 2014.

Evans, M. J. and Jacob, D. J.: Impact of new laboratory studies of $\mathrm{N}_{2} \mathrm{O}_{5}$ hydrolysis on global model budgets of tropospheric nitrogen oxides, ozone, and OH, Geophys. Res. Lett., 32, L09813, https://doi.org/10.1029/2005GL022469, 2005.

Faxon, C., Bean, J., and Ruiz, L.: Inland Concentrations of $\mathrm{Cl}_{2}$ and $\mathrm{ClNO}_{2}$ in Southeast Texas Suggest Chlorine Chemistry Significantly Contributes to Atmospheric Reactivity, Atmosphere, 6, 1487-1506, https://doi.org/10.3390/atmos6101487, 2015.

Fickert, S., Helleis, F., Adams, J. W., Moortgat, G. K., and Crowley, J. N.: Reactive uptake of $\mathrm{ClNO}_{2}$ on aqueous bromide solutions, J. Phys. Chem. A, 102, 10689-10696, https://doi.org/10.1021/jp983004n, 1998.

Fickert, S., Adams, J. W., and Crowley, J. N.: Activation of $\mathrm{Br}_{2}$ and $\mathrm{BrCl}$ via uptake of $\mathrm{HOBr}$ onto aqueous salt solutions, J. Geophys. Res.-Atmos., 104, 23719-23727, https://doi.org/10.1029/1999JD900359, 1999.

Finlayson-Pitts, B. J.: The Tropospheric Chemistry of Sea Salt: A Molecular-Level View of the Chemistry of $\mathrm{NaCl}$ and $\mathrm{NaBr}$, Chem. Rev., 103, 4801-4822, https://doi.org/10.1021/cr020653t, 2003.

Fountoukis, C. and Nenes, A.: ISORROPIA II: a computationally efficient thermodynamic equilibrium model for $\mathrm{K}^{+}-\mathrm{Ca}^{2+}-\mathrm{Mg}^{2+}-\mathrm{NH}_{4}^{+}-\mathrm{Na}^{+}-\mathrm{SO}_{4}^{2-}-\mathrm{NO}^{-}-\mathrm{Cl}^{-}-\mathrm{H}_{2} \mathrm{O}$ aerosols, Atmos. Chem. Phys., 7, 4639-4659, https://doi.org/10.5194/acp-7-4639-2007, 2007.

Frenzel, A., Scheer, V., Sikorski, R., George, C., Behnke, W., and Zetzsch, C.: Heterogeneous Interconversion Reactions of $\mathrm{BRNO}_{2}, \mathrm{ClNO}_{2}, \mathrm{Br}_{2}$, and $\mathrm{Cl}_{2}$, J. Phys. Chem. A, 102, 13291337, https://doi.org/10.1021/jp973044b, 1998.

Fridlind, A. M. and Jacobson, M. Z.: A study of gas-aerosol equilibrium and aerosol $\mathrm{pH}$ in the remote marine boundary layer during the First Aerosol Characterization Experiment (ACE 1), J. Geophys. Res.-Atmos., 105, 17325-17340, https://doi.org/10.1029/2000JD900209, 2000.

Giglio, L., Randerson, J. T., and van der Werf, G. R.: Analysis of daily, monthly, and annual burned area using the fourthgeneration global fire emissions database (GFED4), J. Geophys. Res.-Biogeo., 118, 317-328, https://doi.org/10.1002/jgrg.20042, 2013.

Graedel, T. E. and Keene, W. C.: Tropospheric budget of reactive chlorine, Global Biogeochem. Cy., 9, 47-77, https://doi.org/10.1029/94GB03103, 1995.

Gromov, S., Brenninkmeijer, C. A. M., and Jöckel, P.: A very limited role of tropospheric chlorine as a sink of the greenhouse gas methane, Atmos. Chem. Phys., 18, 9831-9843, https://doi.org/10.5194/acp-18-9831-2018, 2018.

Guo, H., Sullivan, A. P., Campuzano-Jost, P., Schroder, J. C., LopezHilfiker, F. D., Dibb, J. E., Jimenez, J. L., Thornton, J. A., Brown, S. S., Nenes, A., and Weber, R. J.: Fine particle pH and the partitioning of nitric acid during winter in the northeastern United States, J. Geophys. Res.-Atmos., 121, 10355-10376, https://doi.org/10.1002/2016JD025311, 2016.

Gurciullo, C., Lerner, B., Sievering, H., and Pandis, S. N.: Heterogeneous sulfate production in the remote marine environment:
Cloud processing and sea-salt particle contributions, J. Geophys. Res., 104, 21719-21731, 1999.

Haskins, J. D., Jaeglé, L., Shah, V., Lee, B. H., Lopez-Hilfiker, F. D., Campuzano-Jost, P., Schroder, J. C., Day, D. A., Guo, H., Sullivan, A. P., Weber, R., Dibb, J., Campos, T., Jimenez, J. L., Brown, S. S., and Thornton, J. A.: Wintertime GasParticle Partitioning and Speciation of Inorganic Chlorine in the Lower Troposphere Over the Northeast United States and Coastal Ocean, J. Geophys. Res.-Atmos., 123, 12897-12916, https://doi.org/10.1029/2018JD028786, 2018.

Hoffmann, E. H., Tilgner, A., Schrödner, R., Bräuer, P., Wolke, R., and Herrmann, H.: An advanced modeling study on the impacts and atmospheric implications of multiphase dimethyl sulfide chemistry, P. Natl. Acad. Sci. USA, 113, 11776-11781, https://doi.org/10.1073/pnas.1606320113, 2016.

Holmes, C. D., Jacob, D. J., and Yang, X.: Global lifetime of elemental mercury against oxidation by atomic bromine in the free troposphere, Geophys. Res. Lett., 33, L20808, https://doi.org/10.1029/2006GL027176, 2006.

Horowitz, H. M., Jacob, D. J., Zhang, Y., Dibble, T. S., Slemr, F., Amos, H. M., Schmidt, J. A., Corbitt, E. S., Marais, E. A., and Sunderland, E. M.: A new mechanism for atmospheric mercury redox chemistry: implications for the global mercury budget, Atmos. Chem. Phys., 17, 6353-6371, https://doi.org/10.5194/acp17-6353-2017, 2017.

Hossaini, R., Chipperfield, M. P., Saiz-Lopez, A., Fernandez, R., Monks, S., Feng, W., Brauer, P., and von Glasow, R.: A global model of tropospheric chlorine chemistry: Organic versus inorganic sources and impact on methane oxidation, J. Geophys. Res.-Atmos., 121, 14271-14297, https://doi.org/10.1002/2016JD025756, 2016.

Impey, G. A., Mihele, C. M., Anlauf, K. G., Barrie, L. A., Hastie, D. R., and Shepson, P. B.: Measurements of Photolyzable Halogen Compounds and Bromine Radicals During the Polar Sunrise Experiment 1997, J. Atmos. Chem., 34, 21-37, https://doi.org/10.1023/a:1006264912394, 1999.

Jacob, D. J.: Heterogeneous chemistry and tropospheric ozone, Atmos. Environ., 34, 2131-2159, https://doi.org/10.1016/S13522310(99)00462-8, 2000.

Jacob, D. J., Waldman, J. M., Munger, J. W., and Hoffmann, M. R.: Chemical composition of fogwater collected along the California coast, Environ. Sci. Technol., 19, 730-736, https://doi.org/10.1021/es00138a013, 1985.

Jaeglé, L., Quinn, P. K., Bates, T. S., Alexander, B., and Lin, J.-T.: Global distribution of sea salt aerosols: new constraints from in situ and remote sensing observations, Atmos. Chem. Phys., 11, 3137-3157, https://doi.org/10.5194/acp-11-3137-2011, 2011.

Jaeglé, L., Shah, V., Thornton, J. A., Lopez-Hilfiker, F. D., Lee, B. H., McDuffie, E. E., Fibiger, D., Brown, S. S., Veres, P., Sparks, T. L., Ebben, C. J., Wooldridge, P. J., Kenagy, H. S., Cohen, R. C., Weinheimer, A. J., Campos, T. L., Montzka, D. D., Digangi, J. P., Wolfe, G. M., Hanisco, T., Schroder, J. C., Campuzano-Jost, P., Day, D. A., Jimenez, J. L., Sullivan, A. P., Guo, H., and Weber, R. J.: Nitrogen Oxides Emissions, Chemistry, Deposition, and Export Over the Northeast United States During the WINTER Aircraft Campaign, J. Geophys. Res.-Atmos., 123, 12368 12393, https://doi.org/10.1029/2018JD029133, 2018.

Jeong, D., Seco, R., Gu, D., Lee, Y., Nault, B. A., Knote, C. J., Mcgee, T., Sullivan, J. T., Jimenez, J. L., Campuzano-Jost, P., 
Blake, D. R., Sanchez, D., Guenther, A. B., Tanner, D., Huey, L. G., Long, R., Anderson, B. E., Hall, S. R., Ullmann, K., Shin, H.-J., Herndon, S. C., Lee, Y., Kim, D., Ahn, J., and Kim, S.: Integration of Airborne and Ground Observations of Nitryl Chloride in the Seoul Metropolitan Area and the Implications on Regional Oxidation Capacity During KORUS-AQ 2016, Atmos. Chem. Phys. Discuss., https://doi.org/10.5194/acp-2018-1216, in review, 2018.

Kasibhatla, P., Sherwen, T., Evans, M. J., Carpenter, L. J., Reed, C., Alexander, B., Chen, Q., Sulprizio, M. P., Lee, J. D., Read, K. A., Bloss, W., Crilley, L. R., Keene, W. C., Pszenny, A. A. P., and Hodzic, A.: Global impact of nitrate photolysis in sea-salt aerosol on $\mathrm{NO}_{x}, \mathrm{OH}$, and $\mathrm{O} ? 3$ in the marine boundary layer, Atmos. Chem. Phys., 18, 11185-11203, https://doi.org/10.5194/acp-1811185-2018, 2018

Keene, W. C., Pszenny, A. A. P., Jacob, D. J., Duce, R. A., Galloway, J. N., Schultz-Tokos, J. J., Sievering, H., and Boatman, J. F.: The geochemical cycling of reactive chlorine through the marine troposphere, Global Biogeochem. Cy., 4, 407-430, https://doi.org/10.1029/GB004i004p00407, 1990.

Keene, W. C., Stutz, J., Pszenny, A. A. P., Maben, J. R., Fischer, E. V., Smith, A. M., von Glasow, R., Pechtl, S., Sive, B. C., and Varner, R. K.: Inorganic chlorine and bromine in coastal New England air during summer, J. Geophys. Res.-Atmos., 112, D10S12, https://doi.org/10.1029/2006jd007689, 2007.

Keene, W. C., Long, M. S., Pszenny, A. A. P., Sander, R., Maben, J. R., Wall, A. J., O’Halloran, T. L., Kerkweg, A., Fischer, E. V., and Schrems, O.: Latitudinal variation in the multiphase chemical processing of inorganic halogens and related species over the eastern North and South Atlantic Oceans, Atmos. Chem. Phys., 9, 7361-7385, https://doi.org/10.5194/acp-9-7361-2009, 2009.

Kelly, J. T., Bhave, P. V., Nolte, C. G., Shankar, U., and Foley, K. M.: Simulating emission and chemical evolution of coarse sea-salt particles in the Community Multiscale Air Quality (CMAQ) model, Geosci. Model Dev., 3, 257-273, https://doi.org/10.5194/gmd-3-257-2010, 2010.

Kercher, J. P., Riedel, T. P., and Thornton, J. A.: Chlorine activation by $\mathrm{N}_{2} \mathrm{O}_{5}$ : simultaneous, in situ detection of $\mathrm{ClNO}_{2}$ and $\mathrm{N}_{2} \mathrm{O}_{5}$ by chemical ionization mass spectrometry, Atmos. Meas. Tech., 2, 193-204, https://doi.org/10.5194/amt-2-193-2009, 2009.

Kim, S., Huey, L. G., Stickel, R. E., Pierce, R. B., Chen, G., Avery, M. A., Dibb, J. E., Diskin, G. S., Sachse, G. W., McNaughton, C. S., Clarke, A. D., Anderson, B. E., and Blake, D. R.: Airborne measurements of $\mathrm{HCl}$ from the marine boundary layer to the lower stratosphere over the North Pacific Ocean during INTEX-B, Atmos. Chem. Phys. Discuss., 8, 3563-3595, https://doi.org/10.5194/acpd-8-3563-2008, 2008.

Kim, M. J., Farmer, D. K., and Bertram, T. H.: A controlling role for the air-sea interface in the chemical processing of reactive nitrogen in the coastal marine boundary layer, P. Natl. Acad. Sci. USA, 111, 3943-3948, https://doi.org/10.1073/pnas.1318694111, 2014.

Knipping, E. M. and Dabdub, D.: Modeling $\mathrm{Cl}_{2}$ formation from aqueous $\mathrm{NaCl}$ particles: Evidence for interfacial reactions and importance of $\mathrm{Cl}_{2}$ decomposition in alkaline solution, J. Geophys. Res.-Atmos., 107, 4360, https://doi.org/10.1029/2001JD000867, 2002.
Koepke, P., Hess, M., Schult, I., and Shettle, E. P.: Global Aerosol Data Set, Report No. 243, Max-Planck-Institut für Meteorologie, Hamburg, 1997.

Kolesar, K. R., Mattson, C. N., Peterson, P. K., May, N. W., Prendergast, R. K., and Pratt, K. A.: Increases in wintertime $\mathrm{PM}_{2.5}$ sodium and chloride linked to snowfall and road salt application, Atmos. Environ., 177, 195-202, https://doi.org/10.1016/j.atmosenv.2018.01.008, 2018.

Koo, B., Gaydos, T. M., and Pandis, S. N.: Evaluation of the Equilibrium, Dynamic, and Hybrid Aerosol Modeling Approaches, Aerosol. Sci. Tech., 37, 53-64, https://doi.org/10.1080/02786820300893, 2003.

Lawler, M. J., Finley, B. D., Keene, W. C., Pszenny, A. A. P., Read, K. A., von Glasow, R., and Saltzman, E. S.: Pollutionenhanced reactive chlorine chemistry in the eastern tropical Atlantic boundary layer, Geophys. Res. Lett., 36, L08810, https://doi.org/10.1029/2008g1036666, 2009.

Lawler, M. J., Sander, R., Carpenter, L. J., Lee, J. D., von Glasow, R., Sommariva, R., and Saltzman, E. S.: $\mathrm{HOCl}$ and $\mathrm{Cl}_{2}$ observations in marine air, Atmos. Chem. Phys., 11, 7617-7628, https://doi.org/10.5194/acp-11-7617-2011, 2011.

Lee, B. H., Lopez-Hilfiker, F. D., Schroder, J. C., Campuzano-Jost, P., Jimenez, J. L., McDuffie, E. E., Fibiger, D. L., Veres, P. R., Brown, S. S., Campos, T. L., Weinheimer, A. J., Flocke, F. F., Norris, G., O’Mara, K., Green, J. R., Fiddler, M. N., Bililign, S., Shah, V., Jaeglé, L., and Thornton, J. A.: Airborne Observations of Reactive Inorganic Chlorine and Bromine Species in the Exhaust of Coal-Fired Power Plants, J. Geophys. Res.-Atmos., 123, 11225-11237, https://doi.org/10.1029/2018jd029284, 2018.

Lewis, E. and Schwartz, S.: Comment on "size distribution of seasalt emissions as a function of relative humidity", Atmos. Env. 40, 588-590, 2006.

Lewis, E. and Schwartz, S.: Sea Salt Aerosol Production: Mechanisms, Methods, Measurements and Models, Geophys. Monogr. Ser., Vol. 152, AGU, Washington, D.C., https://doi.org/10.1029/GM152, 2014.

Liao, J., Huey, L. G., Liu, Z., Tanner, D. J., Cantrell, C. A., Orlando, J. J., Flocke, F. M., Shepson, P. B., Weinheimer, A. J., Hall, S. R., Ullmann, K., Beine, H. J., Wang, Y., Ingall, E. D., Stephens, C. R., Hornbrook, R. S., Apel, E. C., Riemer, D., Fried, A., Mauldin, R. L., Smith, J. N., Staebler, R. M., Neuman, J. A., and Nowak, J. B.: High levels of molecular chlorine in the Arctic atmosphere, Nat. Geosci., 7, 91-94, https://doi.org/10.1038/ngeo2046, 2014.

Liu, H., Jacob, D. J., Bey, I., and Yantosca, R. M.: Constraints from ${ }^{210} \mathrm{~Pb}$ and ${ }^{7} \mathrm{Be}$ on wet deposition and transport in a global threedimensional chemical tracer model driven by assimilated meteorological fields, J. Geophys. Res.-Atmos., 106, 12109-12128, https://doi.org/10.1029/2000JD900839, 2001.

Liu, Q. and Margerum, D. W.: Equilibrium and Kinetics of Bromine Chloride Hydrolysis, Environ. Sci. Technol., 35, 1127-1133, https://doi.org/10.1021/es001380r, 2001.

Liu, Y., Fan, Q., Chen, X., Zhao, J., Ling, Z., Hong, Y., Li, W., Chen, X., Wang, M., and Wei, X.: Modeling the impact of chlorine emissions from coal combustion and prescribed waste incineration on tropospheric ozone formation in China, Atmos. Chem. Phys., 18, 2709-2724, https://doi.org/10.5194/acp-182709-2018, 2018.

Lobert, J. M., Keene, W. C., Logan, J. A., and Yevich, R.: Global chlorine emissions from biomass burning: Reactive Chlorine 
Emissions Inventory, J. Geophys. Res.-Atmos., 104, 8373-8389, https://doi.org/10.1029/1998JD100077, 1999.

Long, M. S., Keene, W. C., Easter, R. C., Sander, R., Liu, X., Kerkweg, A., and Erickson, D.: Sensitivity of tropospheric chemical composition to halogen-radical chemistry using a fully coupled size-resolved multiphase chemistry-global climate system: halogen distributions, aerosol composition, and sensitivity of climate-relevant gases, Atmos. Chem. Phys., 14, 3397-3425, https://doi.org/10.5194/acp-14-3397-2014, 2014.

Malm, W. C., Sisler, J. F., Huffman, D., Eldred, R. A., and Cahill, T. A.: Spatial and seasonal trends in particle concentration and optical extinction in the United States, J. Geophys. Res.-Atmos., 99, 1347-1370, https://doi.org/10.1029/93JD02916, 1994.

Martin, R. V., Jacob, D. J., Yantosca, R. M., Chin, M., and Ginoux, P.: Global and regional decreases in tropospheric oxidants from photochemical effects of aerosols, J. Geophys. Res.-Atmos., 108, 4097, https://doi.org/10.1029/2002JD002622, 2003.

Massucci, M., Clegg, S. L., and Brimblecombe, P.: Equilibrium Partial Pressures, Thermodynamic Properties of Aqueous and Solid Phases, and $\mathrm{Cl}_{2}$ Production from Aqueous $\mathrm{HCl}$ and $\mathrm{HNO}_{3}$ and Their Mixtures, J. Phys. Chem. A, 103, 4209-4226, https://doi.org/10.1021/jp9847179, 1999.

McCulloch, A., Aucott, M. L., Benkovitz, C. M., Graedel, T. E., Kleiman, G., Midgley, P. M., and Li, Y.-F.: Global emissions of hydrogen chloride and chloromethane from coal combustion, incineration and industrial activities: Reactive Chlorine Emissions Inventory, J. Geophys. Res.-Atmos., 104, 8391-8403, https://doi.org/10.1029/1999jd900025, 1999.

McDuffie, E. E., Fibiger, D. L., Dubé, W. P., Lopez Hilfiker, F., Lee, B. H., Jaeglé, L., Guo, H., Weber, R. J., Reeves, J. M., Weinheimer, A. J., Schroder, J. C., Campuzano-Jost, P., Jimenez, J. L., Dibb, J. E., Veres, P., Ebben, C., Sparks, T. L., Wooldridge, P. J., Cohen, R. C., Campos, T., Hall, S. R., Ullmann, K., Roberts, J. M., Thornton, J. A., and Brown, S. S.: $\mathrm{ClNO}_{2}$ Yields From Aircraft Measurements During the 2015 WINTER Campaign and Critical Evaluation of the Current Parameterization, J. Geophys. Res.-Atmos., 123, 12994-13015, https://doi.org/10.1029/2018jd029358, 2018a.

McDuffie, E. E., Fibiger, D. L., Dubé, W. P., Lopez-Hilfiker, F., Lee, B. H., Thornton, J. A., Shah, V., Jaeglé, L., Guo, H., Weber, R. J., Michael Reeves, J., Weinheimer, A. J., Schroder, J. C., Campuzano-Jost, P., Jimenez, J. L., Dibb, J. E., Veres, P., Ebben, C., Sparks, T. L., Wooldridge, P. J., Cohen, R. C., Hornbrook, R. S., Apel, E. C., Campos, T., Hall, S. R., Ullmann, K., and Brown, S. S.: Heterogeneous $\mathrm{N}_{2} \mathrm{O}_{5}$ Uptake During Winter: Aircraft Measurements During the 2015 WINTER Campaign and Critical Evaluation of Current Parameterizations, J. Geophys. Res.-Atmos., 123, 4345-4372, https://doi.org/10.1002/2018JD028336, 2018b.

Meng, Z. and Seinfeld, J. H.: Time scales to achieve atmospheric gas-aerosol equilibrium for volatile species, Atmos. Environ., 30, 2889-2900, https://doi.org/10.1016/1352-2310(95)00493-9, 1996.

Mielke, L. H., Furgeson, A., and Osthoff, H. D.: Observation of $\mathrm{ClNO}_{2}$ in a Mid-Continental Urban Environment, Environ. Sci. Technol., 45, 8889-8896, https://doi.org/10.1021/es201955u, 2011.

Mielke, L. H., Stutz, J., Tsai, C., Hurlock, S. C., Roberts, J. M., Veres, P. R., Froyd, K. D., Hayes, P. L., Cubison, M. J., Jimenez,
J. L., Washenfelder, R. A., Young, C. J., Gilman, J. B., de Gouw, J. A., Flynn, J. H., Grossberg, N., Lefer, B. L., Liu, J., Weber, R. J., and Osthoff, H. D.: Heterogeneous formation of nitryl chloride and its role as a nocturnal $\mathrm{NO}_{x}$ reservoir species during CalNex-LA 2010, J. Geophys. Res.-Atmos., 118, 10638-10652, https://doi.org/10.1002/jgrd.50783, 2013.

Mielke, L. H., Furgeson, A., Odame-Ankrah, C. A., and Osthoff, H. D.: Ubiquity of $\mathrm{ClNO}_{2}$ in the urban boundary layer of Calgary, Alberta, Canada, Can. J. Chem., 94, 414-423, https://doi.org/10.1139/cjc-2015-0426, 2015.

Millet, D. B., Guenther, A., Siegel, D. A., Nelson, N. B., Singh, H. B., de Gouw, J. A., Warneke, C., Williams, J., Eerdekens, G., Sinha, V., Karl, T., Flocke, F., Apel, E., Riemer, D. D., Palmer, P. I., and Barkley, M.: Global atmospheric budget of acetaldehyde: 3-D model analysis and constraints from in-situ and satellite observations, Atmos. Chem. Phys., 10, 3405-3425, https://doi.org/10.5194/acp-10-3405-2010, 2010.

Murray, L. T., Jacob, D. J., Logan, J. A., Hudman, R. C., and Koshak, W. J.: Optimized regional and interannual variability of lightning in a global chemical transport model constrained by LIS/OTD satellite data, J. Geophys. Res.-Atmos., 117, D20307, https://doi.org/10.1029/2012JD017934, 2012.

Naik, V., Voulgarakis, A., Fiore, A. M., Horowitz, L. W., Lamarque, J.-F., Lin, M., Prather, M. J., Young, P. J., Bergmann, D., Cameron-Smith, P. J., Cionni, I., Collins, W. J., Dalsøren, S. B., Doherty, R., Eyring, V., Faluvegi, G., Folberth, G. A., Josse, B., Lee, Y. H., MacKenzie, I. A., Nagashima, T., van Noije, T. P. C., Plummer, D. A., Righi, M., Rumbold, S. T., Skeie, R., Shindell, D. T., Stevenson, D. S., Strode, S., Sudo, K., Szopa, S., and Zeng, G.: Preindustrial to present-day changes in tropospheric hydroxyl radical and methane lifetime from the Atmospheric Chemistry and Climate Model Intercomparison Project (ACCMIP), Atmos. Chem. Phys., 13, 5277-5298, https://doi.org/10.5194/acp13-5277-2013, 2013.

Ordóñez, C., Lamarque, J.-F., Tilmes, S., Kinnison, D. E., Atlas, E. L., Blake, D. R., Sousa Santos, G., Brasseur, G., and Saiz-Lopez, A.: Bromine and iodine chemistry in a global chemistry-climate model: description and evaluation of very short-lived oceanic sources, Atmos. Chem. Phys., 12, 14231447, https://doi.org/10.5194/acp-12-1423-2012, 2012.

Osthoff, H. D., Roberts, J. M., Ravishankara, A. R., Williams, E. J., Lerner, B. M., Sommariva, R., Bates, T. S., Coffman, D., Quinn, P. K., Dibb, J. E., Stark, H., Burkholder, J. B., Talukdar, R. K., Meagher, J., Fehsenfeld, F. C., and Brown, S. S.: High levels of nitryl chloride in the polluted subtropical marine boundary layer, Nat. Geosci., 1, 324-328, https://doi.org/10.1038/ngeo177, 2008.

Parrella, J. P., Jacob, D. J., Liang, Q., Zhang, Y., Mickley, L. J., Miller, B., Evans, M. J., Yang, X., Pyle, J. A., Theys, N., and Van Roozendael, M.: Tropospheric bromine chemistry: implications for present and pre-industrial ozone and mercury, Atmos. Chem. Phys., 12, 6723-6740, https://doi.org/10.5194/acp12-6723-2012, 2012.

Philip, S., Martin, R. V., Snider, G., Weagle, C. L., van Donkelaar, A., Brauer, M., Henze, D. K., Klimont, Z., Venkataraman, C., Guttikunda, S. K., and Zhang, Q.: Anthropogenic fugitive, combustion and industrial dust is a significant, underrepresented fine particulate matter source in global atmospheric models, 
Environ. Res. Lett., 12, 044018, https://doi.org/10.1088/17489326/aa65a4, 2017.

Phillips, G. J., Tang, M. J., Thieser, J., Brickwedde, B., Schuster, G., Bohn, B., Lelieveld, J., and Crowley, J. N.: Significant concentrations of nitryl chloride observed in rural continental Europe associated with the influence of sea salt chloride and anthropogenic emissions, Geophys. Res. Lett., 39, L10811, https://doi.org/10.1029/2012g1051912, 2012.

Pilinis, C., Capaldo, K. P., Nenes, A., and Pandis, S. N.: MADM-A New Multicomponent Aerosol Dynamics Model, Aerosol. Sci. Tech., 32, 482-502, https://doi.org/10.1080/027868200303597, 2000.

Platt, U., Allan, W., and Lowe, D.: Hemispheric average $\mathrm{Cl}$ atom concentration from ${ }^{13} \mathrm{C} /{ }^{12} \mathrm{C}$ ratios in atmospheric methane, Atmos. Chem. Phys., 4, 2393-2399, https://doi.org/10.5194/acp-42393-2004, 2004.

Priestley, M., le Breton, M., Bannan, T. J., Worrall, S. D., Bacak, A., Smedley, A. R. D., Reyes-Villegas, E., Mehra, A., Allan, J., Webb, A. R., Shallcross, D. E., Coe, H., and Percival, C. J.: Observations of organic and inorganic chlorinated compounds and their contribution to chlorine radical concentrations in an urban environment in northern Europe during the wintertime, Atmos. Chem. Phys., 18, 13481-13493, https://doi.org/10.5194/acp-1813481-2018, 2018

Prinn, R. G., Weiss, R. F., Arduini, J., Arnold, T., DeWitt, H. L., Fraser, P. J., Ganesan, A. L., Gasore, J., Harth, C. M., Hermansen, O., Kim, J., Krummel, P. B., Li, S., Loh, Z. M., Lunder, C. R., Maione, M., Manning, A. J., Miller, B. R., Mitrevski, B., Mühle, J., O’Doherty, S., Park, S., Reimann, S., Rigby, M., Saito, T., Salameh, P. K., Schmidt, R., Simmonds, P. G., Steele, L. P., Vollmer, M. K., Wang, R. H., Yao, B., Yokouchi, Y., Young, D., and Zhou, L.: History of chemically and radiatively important atmospheric gases from the Advanced Global Atmospheric Gases Experiment (AGAGE), Earth Syst. Sci. Data, 10, 9851018, https://doi.org/10.5194/essd-10-985-2018, 2018.

Pszenny, A. A. P., Keene, W. C., Jacob, D. J., Fan, S., Maben, J. R., Zetwo, M. P., Springer-Young, M., and Galloway, J. N.: Evidence of inorganic chlorine gases other than hydrogen chloride in marine surface air, Geophys. Res. Lett., 20, 699-702, https://doi.org/10.1029/93GL00047, 1993.

Pszenny, A. A. P., Moldanová, J., Keene, W. C., Sander, R., Maben, J. R., Martinez, M., Crutzen, P. J., Perner, D., and Prinn, R. G.: Halogen cycling and aerosol pH in the Hawaiian marine boundary layer, Atmos. Chem. Phys., 4, 147-168, https://doi.org/10.5194/acp-4-147-2004, 2004.

Reff, A., Bhave, P. V., Simon, H., Pace, T. G., Pouliot, G. A., Mobley, J. D., and Houyoux, M.: Emissions Inventory of $\mathrm{PM}_{2.5}$ Trace Elements across the United States, Environ. Sci. Technol., 43, 5790-5796, https://doi.org/10.1021/es802930x, 2009.

Riedel, T. P., Wagner, N. L., Dubé, W. P., Middlebrook, A. M., Young, C. J., Öztürk, F., Bahreini, R., VandenBoer, T. C., Wolfe, D. E., Williams, E. J., Roberts, J. M., Brown, S. S., and Thornton, J. A.: Chlorine activation within urban or power plant plumes: Vertically resolved $\mathrm{ClNO}_{2}$ and $\mathrm{Cl}_{2}$ measurements from a tall tower in a polluted continental setting, J. Geophys. Res.-Atmos., 118, 8702-8715, https://doi.org/10.1002/jgrd.50637, 2013.

Roberts, J. M., Osthoff, H. D., Brown, S. S., and Ravishankara, A. R.: $\mathrm{N}_{2} \mathrm{O}_{5}$ Oxidizes Chloride to $\mathrm{Cl}_{2}$ in
Acidic Atmospheric Aerosol, Science, 321, 1059-1059, https://doi.org/10.1126/science.1158777, 2008.

Roberts, J. M., Osthoff, H. D., Brown, S. S., Ravishankara, A. R., Coffman, D., Quinn, P., and Bates, T.: Laboratory studies of products of $\mathrm{N}_{2} \mathrm{O}_{5}$ uptake on $\mathrm{Cl}^{-}$containing substrates, Geophys. Res. Lett., 36, L20808, https://doi.org/10.1029/2009GL040448, 2009.

Saiz-Lopez, A. and von Glasow, R.: Reactive halogen chemistry in the troposphere, Chem. Soc. Rev., 41, 6448-6472, https://doi.org/10.1039/c2cs35208g, 2012.

Saiz-Lopez, A., Fernandez, R. P., Ordóñez, C., Kinnison, D. E., Gómez Martín, J. C., Lamarque, J.-F., and Tilmes, S.: Iodine chemistry in the troposphere and its effect on ozone, Atmos. Chem. Phys., 14, 13119-13143, https://doi.org/10.5194/acp-1413119-2014, 2014.

Sander, R.: Compilation of Henry's law constants (version 4.0) for water as solvent, Atmos. Chem. Phys., 15, 4399-4981, https://doi.org/10.5194/acp-15-4399-2015, 2015.

Sander, R., Pszenny, A. A. P., Keene, W. C., Crete, E., Deegan, B., Long, M. S., Maben, J. R., and Young, A. H.: Gas phase acid, ammonia and aerosol ionic and trace element concentrations at Cape Verde during the Reactive Halogens in the Marine Boundary Layer (RHaMBLe) 2007 intensive sampling period, Earth Syst. Sci. Data, 5, 385-392, https://doi.org/10.5194/essd-5-3852013, 2013.

Sanhueza, E., and Garaboto, A.: Gaseous $\mathrm{HCl}$ at a remote tropical continental site, Tellus B, 54, 412-415, https://doi.org/10.3402/tellusb.v54i4.16675, 2002.

Sarwar, G., Simon, H., Bhave, P., and Yarwood, G.: Examining the impact of heterogeneous nitryl chloride production on air quality across the United States, Atmos. Chem. Phys., 12, 6455-6473, https://doi.org/10.5194/acp-12-6455-2012, 2012.

Sarwar, G., Simon, H., Xing, J., and Mathur, R.: Importance of tropospheric $\mathrm{ClNO}_{2}$ chemistry across the Northern Hemisphere, Geophys. Res. Lett., 41, 4050-4058, https://doi.org/10.1002/2014GL059962, 2014.

Schmidt, J. A., Jacob, D. J., Horowitz, H. M., Hu, L., Sherwen, T., Evans, M. J., Liang, Q., Suleiman, R. M., Oram, D. E., Le Breton, M., Percival, C. J., Wang, S., Dix, B., and Volkamer, R.: Modeling the observed tropospheric BrO background: Importance of multiphase chemistry and implications for ozone, $\mathrm{OH}$, and mercury, J. Geophys. Res.-Atmos., 121, 11819-11835, https://doi.org/10.1002/2015jd024229, 2016.

Schweitzer, F., Mirabel, P., and George, C.: Multiphase Chemistry of $\mathrm{N}_{2} \mathrm{O}_{5}, \mathrm{ClNO}_{2}$, and $\mathrm{BrNO}_{2}$, J. Phys. Chem. A, 102, 39423952, https://doi.org/10.1021/jp980748s, 1998.

Sherwen, T., Evans, M. J., Carpenter, L. J., Andrews, S. J., Lidster, R. T., Dix, B., Koenig, T. K., Sinreich, R., Ortega, I., Volkamer, R., Saiz-Lopez, A., Prados-Roman, C., Mahajan, A. S., and Ordóñez, C.: Iodine's impact on tropospheric oxidants: a global model study in GEOS-Chem, Atmos. Chem. Phys., 16, 11611186, https://doi.org/10.5194/acp-16-1161-2016, 2016 a.

Sherwen, T., Schmidt, J. A., Evans, M. J., Carpenter, L. J., Großmann, K., Eastham, S. D., Jacob, D. J., Dix, B., Koenig, T. K., Sinreich, R., Ortega, I., Volkamer, R., Saiz-Lopez, A., PradosRoman, C., Mahajan, A. S., and Ordóñez, C.: Global impacts of tropospheric halogens $(\mathrm{Cl}, \mathrm{Br}, \mathrm{I})$ on oxidants and composition in GEOS-Chem, Atmos. Chem. Phys., 16, 12239-12271, https://doi.org/10.5194/acp-16-12239-2016, 2016 b. 
Sherwen, T., Evans, M. J., Sommariva, R., Hollis, L. D. J., Ball, S. M., Monks, P. S., Reed, C., Carpenter, L. J., Lee, J. D., Forster, G., Bandy, B., Reeves, C. E., and Bloss, W. J.: Effects of halogens on European air-quality, Faraday Discuss., 200, 75-100, https://doi.org/10.1039/c7fd00026j, 2017.

Simmonds, P. G., Manning, A. J., Cunnold, D. M., McCulloch, A., O’Doherty, S., Derwent, R. G., Krummel, P. B., Fraser, P. J., Dunse, B., Porter, L. W., Wang, R. H. J., Greally, B. R., Miller, B. R., Salameh, P., Weiss, R. F., and Prinn, R. G.: Global trends, seasonal cycles, and European emissions of dichloromethane, trichloroethene, and tetrachloroethene from the AGAGE observations at Mace Head, Ireland, and Cape Grim, Tasmania, J. Geophys. Res.-Atmos., 111, D18304, https://doi.org/10.1029/2006JD007082, 2006.

Simpson, W. R., Brown, S. S., Saiz-Lopez, A., Thornton, J. A., and Glasow, R.: Tropospheric halogen chemistry: sources, cycling, and impacts, Chem. Rev., 115, 4035-4062, https://doi.org/10.1021/cr5006638, 2015.

Singh, H. B. and Kasting, J. F.: Chlorine-hydrocarbon photochemistry in the marine troposphere and lower stratosphere, J. Atmos. Chem., 7, 261-285, https://doi.org/10.1007/BF00130933, 1988.

Singh, H. B., Thakur, A. N., Chen, Y. E., and Kanakidou, M.: Tetrachloroethylene as an indicator of low $\mathrm{Cl}$ atom concentrations in the troposphere, Geophys. Res. Lett., 23, 1529-1532, https://doi.org/10.1029/96gl01368, 1996.

Sommariva, R. and von Glasow, R.: Multiphase halogen chemistry in the tropical Atlantic Ocean, Environ. Sci. Technol., 46, 1042910437, https://doi.org/10.1021/es300209f, 2012.

Sommariva, R., Hollis, L. D. J., Sherwen, T., Baker, A. R., Ball, S. M., Bandy, B. J., Bell, T. G., Chowdhury, M. N., Cordell, R. L., Evans, M. J., Lee, J. D., Reed, C., Reeves, C. E., Roberts, J. M., Yang, M., and Monks, P. S.: Seasonal and geographical variability of nitryl chloride and its precursors in Northern Europe, Atmos. Sci. Lett., 19, e844, https://doi.org/10.1002/asl.844, 2018.

Straub, D. J., Lee, T., and Collett Jr., J. L.: Chemical composition of marine stratocumulus clouds over the eastern Pacific Ocean, J. Geophys. Res.-Atmos., 112, D04307, https://doi.org/10.1029/2006JD007439, 2007.

Tham, Y. J., Yan, C., Xue, L., Zha, Q., Wang, X., and Wang, T.: Presence of high nitryl chloride in Asian coastal environment and its impact on atmospheric photochemistry, Chinese Sci. Bull., 59, 356-359, https://doi.org/10.1007/s11434-013-0063-y, 2014.

Thornton, J. A., Kercher, J. P., Riedel, T. P., Wagner, N. L., Cozic, J., Holloway, J. S., Dubé, W. P., Wolfe, G. M., Quinn, P. K., Middlebrook, A. M., Alexander, B., and Brown, S. S.: A large atomic chlorine source inferred from midcontinental reactive nitrogen chemistry, Nature, 464, 271-274, https://doi.org/10.1038/nature08905, 2010.

Toon, O. B., Maring, H., Dibb, J., Ferrare, R., Jacob, D. J., Jensen, E. J., Luo, Z. J., Mace, G. G., Pan, L. L., Pfister, L., Rosenlof, K. H., Redemann, J., Reid, J. S., Singh, H. B., Thompson, A. M., Yokelson, R., Minnis, P., Chen, G., Jucks, K. W., and Pszenny, A.: Planning, implementation, and scientific goals of the Studies of Emissions and Atmospheric Composition, Clouds and Climate Coupling by Regional Surveys (SEAC4RS) field mission, J. Geophys. Res.-Atmos., 121, 49675009, https://doi.org/10.1002/2015JD024297, 2016.

US EPA: 2014 National Emissions Inventory, available at: https://www.epa.gov/air-emissions-inventories/ 2014-national-emissions-inventory-nei-data, last access: 28 August 2018.

van der Werf, G. R., Randerson, J. T., Giglio, L., Collatz, G. J., Mu, M., Kasibhatla, P. S., Morton, D. C., DeFries, R. S., Jin, Y., and van Leeuwen, T. T.: Global fire emissions and the contribution of deforestation, savanna, forest, agricultural, and peat fires (1997-2009), Atmos. Chem. Phys., 10, 11707-11735, https://doi.org/10.5194/acp-10-11707-2010, 2010.

Voulgarakis, A., Naik, V., Lamarque, J.-F., Shindell, D. T., Young, P. J., Prather, M. J., Wild, O., Field, R. D., Bergmann, D., CameronSmith, P., Cionni, I., Collins, W. J., Dalsøren, S. B., Doherty, R. M., Eyring, V., Faluvegi, G., Folberth, G. A., Horowitz, L. W., Josse, B., MacKenzie, I. A., Nagashima, T., Plummer, D. A., Righi, M., Rumbold, S. T., Stevenson, D. S., Strode, S. A., Sudo, K., Szopa, S., and Zeng, G.: Analysis of present day and future $\mathrm{OH}$ and methane lifetime in the ACCMIP simulations, Atmos. Chem. Phys., 13, 2563-2587, https://doi.org/10.5194/acp13-2563-2013, 2013.

Wagner, N. L., Riedel, T. P., Young, C. J., Bahreini, R., Brock, C. A., Dubé, W. P., Kim, S., Middlebrook, A. M., Öztürk, F., Roberts, J. M., Russo, R., Sive, B., Swarthout, R., Thornton, J. A., VandenBoer, T. C., Zhou, Y., and Brown, S. S.: $\mathrm{N}_{2} \mathrm{O}_{5}$ uptake coefficients and nocturnal $\mathrm{NO}_{2}$ removal rates determined from ambient wintertime measurements, J. Geophys. Res.-Atmos., 118, 9331-9350, https://doi.org/10.1002/jgrd.50653, 2013.

Wang, T., Tham, Y. J., Xue, L., Li, Q., Zha, Q., Wang, Z., Poon, S. C. N., Dubé, W. P., Blake, D. R., Louie, P. K. K., Luk, C. W. Y., Tsui, W., and Brown, S. S.: Observations of nitryl chloride and modeling its source and effect on ozone in the planetary boundary layer of southern China, J. Geophys. Res.-Atmos., 121, 2476-2489, https://doi.org/10.1002/2015JD024556, 2016.

Wang, T. X., Kelley, M. D., Cooper, J. N., Beckwith, R. C., and Margerum, D. W.: Equilibrium, Kinetic, and UV-Spectral Characteristics of Aqueous Bromine Chloride, Bromine, and Chlorine Species, Inorg. Chem., 33, 5872-5878, https://doi.org/10.1021/ic00103a040, 1994.

Wang, Y., Jacob, D. J., and Logan, J. A.: Global simulation of tropospheric $\mathrm{O}_{3}-\mathrm{NO}_{x}$-hydrocarbon chemistry: 1. Model formulation, J. Geophys. Res.-Atmos., 103, 10713-10725, https://doi.org/10.1029/98JD00158, 1998.

Wesely, M. L.: Parameterization of surface resistances to gaseous dry deposition in regional-scale numerical models, Atmos. Environ., 23, 1293-1304, https://doi.org/10.1016/00046981(89)90153-4, 1989.

WMO: Scientific Assessment of Ozone Depletion: 2014, World Meteorological Organization, Global Ozone Research and Monitoring Project - Report No. 55, 416 pp., World Meteorological Organization, Geneva, Switzerland, 2014.

Yang, X., Cox, R. A., Warwick, N. J., Pyle, J. A., Carver, G. D., O'Connor, F. M., and Savage, N. H.: Tropospheric bromine chemistry and its impacts on ozone: A model study, J. Geophys. Res., 110, D23311, https://doi.org/10.1029/2005jd006244, 2005.

Zhu, L., Jacob, D. J., Eastham, S. D., Sulprizio, M. P., Wang, X., Sherwen, T., Evans, M. J., Chen, Q., Alexander, B., Koenig, T. K., Volkamer, R., Huey, L. G., Le Breton, M., Bannan, T. J., and Percival, C. J.: Effect of sea-salt aerosol on tropospheric bromine chemistry, Atmos. Chem. Phys. Discuss. https://doi.org/10.5194/acp-2018-1239, in review, 2018. 